NBER WORKING PAPER SERIES

\title{
CONSTRAINED AFTER COLLEGE: STUDENT LOANS AND EARLY CAREER OCCUPATIONAL CHOICES
}

\author{
Jesse Rothstein \\ Cecilia Elena Rouse \\ Working Paper 13117 \\ http://www.nber.org/papers/w13117
NATIONAL BUREAU OF ECONOMIC RESEARCH
1050 Massachusetts Avenue
Cambridge, MA 02138

May 2007

We thank Jane Fortson, Alan Krueger, Jed Marsh, Robin Moscato, and Harvey Rosen for useful conversations and seminar participants at the CUNY Graduate School, Drexel University, Stanford University, the University of California at Davis, the University of Florida, the University of Wisconsin at Madison, and the American Education Finance Association. We are also indebted to officials at Anon $U$ for the data and to DeForest McDuff, Scott Mildrum and Farrah Parkes for expert research assistance. We thank the Princeton Center for Economic Policy Studies, Education Research Section, and Industrial Relations Section for financial support. The views expressed herein are those of the author(s) and do not necessarily reflect the views of the National Bureau of Economic Research.

(C) 2007 by Jesse Rothstein and Cecilia Elena Rouse. All rights reserved. Short sections of text, not to exceed two paragraphs, may be quoted without explicit permission provided that full credit, including (C) notice, is given to the source. 
Constrained After College: Student Loans and Early Career Occupational Choices

Jesse Rothstein and Cecilia Elena Rouse

NBER Working Paper No. 13117

May 2007

JEL No. D91,H52,I20,J24

\begin{abstract}
$\underline{\text { ABSTRACT }}$
In the early 2000s, a highly selective university introduced a "no-loans" policy under which the loan component of financial aid awards was replaced with grants. We use this natural experiment to identify the causal effect of student debt on employment outcomes. In the standard life-cycle model, young people make optimal educational investment decisions if they are able to finance these investments by borrowing against future earnings; the presence of debt has only income effects on future decisions. We find that debt causes graduates to choose substantially higher-salary jobs and reduces the probability that students choose low-paid "public interest" jobs. We also find some evidence that debt affects students' academic decisions during college. Our estimates suggest that recent college graduates are not life-cycle agents. Two potential explanations are that young workers are credit constrained or that they are averse to holding debt. We find suggestive evidence that debt reduces students' donations to the institution in the years after they graduate and increases the likelihood that a graduate will default on a pledge made during her senior year; we argue this result is more likely consistent with credit constraints than with debt aversion.
\end{abstract}

Jesse Rothstein

Industrial Relations Section

Firestone Library

Princeton University

Princeton, NJ 08544

and NBER

jrothst@ princeton.edu

Cecilia Elena Rouse

Industrial Relations Section

Firestone Library

Princeton University

Princeton, NJ 08544-1013

and NBER

rouse@ princeton.edu 


\section{Introduction}

The returns to a college degree have risen substantially in recent years, but the cost of higher education has risen even more quickly. Between 1993 and 2005, the college wage premium rose by 27 percent (Mishel, Bernstein, and Allegretto 2007) ${ }^{1}$, while real tuition and fees at public and private four-year colleges rose by 63 percent and 43 percent, respectively (Trends in College Pricing 2005, Table A1). ${ }^{2}$ These rising costs have made financial aid more important. The proportion of full-time, full-year undergraduates receiving financial aid rose from 58.7 percent in 1993 to 76.1 percent in 2004 (Snyder, Tan, and Hoffman 2006, Table 320).

As aid packages have grown, so has the importance of student loans. The proportion of students on aid who take out at least some loans rose from 55 percent in 1993 to 65 percent in 2004; over the same period, the proportion receiving grant aid fell slightly, from 83 to 82 percent (authors' calculations based on Snyder et al. 2006, Table 320). As a result, college graduates' debt burdens have risen. The average college graduate in 1993 had incurred $\$ 8,462$ in student debt. In 2004, this had risen to $\$ 13,275$. Among those with positive debt, the average rose from $\$ 12,565$ in 1993 to $\$ 20,386$ in $2004 .^{3}$

Some argue that the looming need to make loan payments leads students with debt to major in career-oriented fields or to choose more lucrative post-graduation jobs than would be otherwise optimal. ${ }^{4}$ They also argue that educational debt deters individuals from purchasing

\footnotetext{
${ }^{1} \mathrm{http}: / /$ www.epi.org/datazone/06/wagebyed_a.pdf

${ }^{2}$ All figures in this paper are inflated to 2005 dollars using the CPI-U. The figures for college costs are enrollment-weighted.

${ }^{3}$ Student debt dwarfs another oft-cited source of indebtedness, credit card debt. The average senior in 2004 owed $\$ 512$ in credit card debt (the median was $\$ 0$; the average and median among those with positive credit card debt were $\$ 2,874$ and $\$ 1,654$, respectively). These figures and those in the text are computed from the 1992-3 and 2003-4 National Postsecondary Student Aid Surveys (NPSAS; see Loft et al. 1995 and Cominole et al. 2006).

${ }^{4}$ See, for example, Kamenetz (2006). A nationwide survey conducted by the Nellie Mae Corporation in 2002 found that 17 percent of student loan borrowers reported the loans had significantly impacted their career plans (Baum and O’Malley 2003). Minicozzi (2005) analyzes data from the National Postsecondary Student Aid Survey,
} 
homes or getting married, or assuming other responsibilities typically associated with fullfledged adulthood (Chiteji 2007).

The traditional economic view of borrowing and saving rules out these sorts of effects. In a standard life-cycle model, student debt has only an income effect - proportional to the ratio of debt to the present discounted value of total lifetime earnings - on career and other postcollege decisions. As debt represents just over one percent of lifetime earnings for a typical college graduate, we expect any such effects to be extremely small.

One reason debt may nonetheless matter is that young people - particularly those from disadvantaged backgrounds - may be "debt averse" (see, e.g., Burdman 2005, Callender and Jackson 2004, and Field 2005). If holding debt reduces utility independent of any effects on consumption, recent graduates may attempt to repay loans quickly or otherwise act as if debt payments are more constraining than they really are. ${ }^{5}$

A second potential source of non-trivial debt effects on post-graduation decisions is a failure of capital markets. While much of the literature in education focuses on students' access to credit before and during college (see the discussion below), credit constraints after college graduation can also affect decisions. Young workers' current annual incomes are typically much lower than their permanent incomes, and many may prefer to borrow to finance current consumption. If recent graduates are unable to do this, student debt will have first-order effects on early-career consumption, and recent graduates may attempt to minimize these effects through their job choices.

and finds that graduates with more educational debt take jobs with higher initial wages and lower rates of wage growth than do those with less debt.

${ }_{5}$ We focus on students who are inframarginal to the college attendance decision, so aversion to taking on debt (as distinct from continuing to hold previously incurred debt) is unlikely to be an important factor. 
There is suggestive evidence from non-educational contexts that many consumers are unable to borrow at reasonable interest rates. For example, Warner and Pleeter (2001) find that a majority of members of the Armed Forces selected a lump sum separation payment over an annuity even though the internal interest rate of the annuity option exceeded $20 \%$. Gross and Souleles (2002) report that well over half of households with credit cards regularly roll over debt, with the median revolving account equal to about $\$ 7,000$ and a typical interest rate around 15 percent. They also find that credit card debt rises, immediately and significantly, when credit limits are increased, especially for those who were already close to their limits. ${ }^{6}$ Finally, Souleles (1999) and Johnson, Parker, and Souleles (2006) find that consumption increases substantially after families receive income tax refunds, where the standard model predicts that predictable income shocks should have no effect on consumption.

In educational settings, the evidence on imperfections in capital markets is mixed and inconclusive. Cameron and Taber (2004) study the impact of borrowing constraints on educational decisions by exploiting the fact that the direct and opportunity costs of education have different effects on credit constrained individuals. They find little evidence that constraints limit otherwise-optimal educational investment. Heckman and Lochner (2000; see also Carneiro and Heckman 2002) also argue that borrowing constraints during the college-going years are not important determinants of college attendance, and that family income affects attendance primarily through its effect on students' academic preparedness. In contrast, Ellwood and Kane (2000) argue that differences in college attendance by family income are partly explained by credit constraints. Stinebrickner and Stinebrickner (undated) conclude that some college

\footnotetext{
${ }^{6}$ In addition, many families pay college tuition bills with credit cards, and roll over the resulting debt. This would not be rational unless these families lacked access to educational loans with lower rates.
} 
students are credit constrained, though they argue that this does not account for family income differences in college persistence.

Our focus in this paper is on the effect of educational debt on students' early career decisions. We take advantage of a unique natural experiment. In the early 2000 s, a wealthy, highly selective university (hereafter referred to as Anonymous University, or "Anon U”) phased in a "no-loans" policy, under which the loan component of financial aid awards was replaced with expanded no-strings-attached grants. Using data on Anon U financial aid recipients before and after the implementation of this policy, we can compare the academic outcomes and career choices of otherwise-identical students who graduated from Anon U with very different debt positions. We also have data on students who did not receive financial aid, which permits us to control for unobserved factors (such as the state of the macroeconomy) that might have led to different outcomes for students in the pre- and post-reform cohorts even in the absence of the policy change. Our empirical strategy combines control function and instrumental variables strategies to take advantage of within- and between-cohort variation in the composition of financial aid packages. The debt effect is identified from changes across cohorts in the debt assigned to otherwise identical students (in particular, to students with the same financial need and family resources).

We find evidence, consistent across several specifications, that debt leads graduates to choose higher-salary jobs. Much or all of this effect is across occupations, as debt appears to reduce the probability that students choose low-paid "public interest" jobs. Debt effects are most notable on the propensity to take a job in the education industry. We also find suggestive (though imprecise) evidence that financial constraints affect students' academic performance during college. 
To help us distinguish whether these effects are due to credit constraints or aversion to debt, we analyze data on alumni pledges and donations. One would expect debt aversion to be reasonably constant over the life cycle, and therefore college seniors should anticipate its effects on their future choices. By contrast, college students may not anticipate the degree to which credit constraints will bind in the period after graduation. ${ }^{7}$ Although our estimates are imprecise, debt seems to have a larger effect on recent graduates' actual gifts to Anon U than it does on the pledges they make during their senior year. This appears to support the credit constraints hypothesis. Because the effect is small and because we can only speculate about the degree to which agents anticipate post-graduation constraints and debt aversion, this interpretation should be taken as suggestive rather than conclusive.

We describe the no-loans policy in more detail in Section II. Section III presents a simple multi-period model of consumption that formalizes the interaction of debt with credit constraints in influencing career decisions. Section IV develops our full estimation strategy, starting from a difference-in-differences estimator and building toward a richer specification that combines control function and instrumental variables methods. We describe in Section V the rich data, drawn from Anon U's administrative records, used for our analysis. Section VI presents results. Section VII discusses the generalizability of our results to wider student populations. Section VIII concludes.

\section{The Anon U Policy Reform}

Anon $\mathrm{U}$ is one of the most selective, expensive colleges in the country, and it admits only the most academically qualified students. It prides itself on the diversity of its students, and it

\footnotetext{
${ }^{7}$ One reason for a failure to anticipate this is that students have access to a variety of government and thirdparty loans on relatively good terms. Access to this sort of credit dries up after graduation, and recent graduates are likely to have to rely on forms of borrowing - e.g., credit cards - that offer substantially worse terms than those they faced during college.
} 
competes with other elite colleges to enroll the relatively few high school graduates of modest means with top academic credentials (Hill and Winston 2006).

In 1998 and again in 2001, Anon U officials announced reforms of their financial aid program to reduce the role of student loans in aid packages. Grants were expanded to fill the gap left by loans, and total nominal aid awards - the sum of the face value of loans, grants, and campus work - were approximately unchanged. As the present value of a grant (which need not be repaid) is much higher than that of even a subsidized loan, these reforms represented a substantial increase in the value of Anon U's aid packages. Officials at Anon U claim the reforms were undertaken to eliminate financial concerns from the decision to apply to or attend the school and to increase the number of low-income students matriculating. The policy was not explicitly undertaken to influence the post-graduation plans of students. ${ }^{8}$

To fully understand the implications of this reform for students, it is useful to consider how Anon U determines a student's financial aid package. Students are admitted to Anon U without regard to their financial circumstances. ${ }^{9}$ Along with her admissions application and in every academic year thereafter, a student may apply for financial aid. The aid application solicits detailed information about the income and assets of the student and her parents. The Anon $U$ financial aid office uses this information to develop an assessment of the family's ability to pay, following a modified (and more generous) version of the formula used by federal aid

\footnotetext{
${ }^{8}$ Financial aid can be seen as a form of price discrimination as generous aid policies allow colleges to reduce the price of attendance for a group of students who are likely to be the most price sensitive without discounting the cost for wealthier students whose demand is likely less elastic. Seen in this light, the policy amounted to an increase in the degree of price discrimination. It also had substantial publicity value as Anon U got a great deal of press attention for its efforts to be more affordable. Linsenmeier, Rosen, and Rouse (2006) find a small demand response to the no-loans policy, with a very small increase in matriculation rates among affected admitted students. Some of Anon U's peer institutions have since announced similar reforms, each to great fanfare.

${ }^{9}$ Anon U, like many other highly endowed universities, promises "need blind" admissions. In fact, there is reason to suspect that Anon $U$ and its competitors give small preferences to needy applicants, as a mechanism for maintaining economic diversity. Bowen, Kurzweil, and Tobin (2005, pp. 101-108), however, find that any such preferences are quite small.
} 
programs. The primary determinants of the "expected family contribution" (EFC) are parental income and assets, though student savings and summertime earnings also enter the calculation. Whenever the EFC falls short of the total annual costs of attendance - tuition, room, board, and an estimate of additional living expenses - the student is judged to need aid. Anon U puts together a personalized aid package that closes the gap. An aid offer has two "self help" components: a student loan and a campus job during the term. Each of these is capped - students are not expected to work more than about 10 hours per week during the term or to incur more than about $\$ 4,500$ in debt per year of enrollment (or approximately $\$ 18,000$ over four years). ${ }^{10}$ Any remaining demonstrated need after reaching the self help limits is met through unconditional grants. ${ }^{11}$

Students may take up their offered aid packages in whole or in part. Not surprisingly, take-up on the grant component - free money - is high. But students commonly substitute among the self-help components, working more during the term and taking on less debt or vice versa. Even the total quantity of self help is elastic: some students take on additional debt in order to relieve the burden on their parents, while others reduce their need by saving more than is expected from summer earnings, consuming less during the year than the aid office budgets, or drawing on more assistance from their parents than was indicated by the aid formula. ${ }^{12}$

${ }^{10}$ The interest rate on loans is subsidized. Estimates of the present value of the subsidy range from about $\$ 0.25$ (Gladieux and Hauptman 1995) to $\$ 0.60$ (Feldstein 1995) per dollar of loans. Similarly, most campus jobs particularly those under the federal "work study" program, which subsidizes the wage bill for the lowest-income of Anon U's students - pay above-market wages.

${ }^{11}$ The formula thus indicates that students whose demonstrated need is less than the sum of the self-help caps are not allocated any grants. There are several exceptions to this, however. First, students who are eligible for federal Pell Grants or who win external scholarships can use these to displace self help. Second, conversations with the Anon U financial aid staff indicate that most students with positive demonstrated need are given at least a token institutional grant. Anon $U$ is unusual in this regard - less wealthy universities will typically give grants only to students with larger need, and are not always able to provide enough aid to meet the full demonstrated need.

${ }^{12}$ Parents may themselves take on debt, through federal "PLUS" loans or unsubsidized loans from Anon U or third-party lenders, but the terms on these are usually worse than those on student debt. 
Under the new Anon U policy, the loan cap was lowered to zero. As neither the formulae for computing expected family contributions and demonstrated need nor the cap on expected term-time earnings changed, this entailed more generous grants for nearly all students on aid. Students were not required to take the full value of this policy through loan reductions; some continued to take out loans in order to reduce term-time work or parent contributions or to permit more consumption during college.

The no-loans policy was implemented in two stages. First, beginning in 1998, loans were eliminated for new matriculants from the class of 2002 and beyond with low family incomes, defined as below about $\$ 40,000$ in nominal dollars. Approximately $18 \%$ of aid recipients from the class of 2002 qualified for this in their freshman year. Students from moderate income families (between $\$ 40,000$ and $\$ 57,500$ ) received partial loan reduction. Students from pre-2002 classes remained under the old regime and continued to receive loans regardless of their family incomes, as did higher-income students (approximately 61 percent of aid recipients) from later cohorts.

In 2001, the no-loans policy was extended to cover all students on aid. This phase applied to all students on campus at the time, regardless of cohort. Thus, a non-low-income student from the class of 2002 was required to take out loans for her first three years on campus but was covered by the no-loans policy during her senior year and therefore was asked to take on 75 percent as much debt over her college career as was a similar student from the class of 2001.

Figure 1 illustrates these changes in policy by showing the total loans offered to students in three hypothetical families with different income levels over four years of attendance. One can see that low-income students were required to take out fewer loans than higher-income students even before the no-loans policy was introduced. Low-income students in the classes of 
2002 and beyond, however, were covered by the first phase of the no-loans policy and were assigned zero loans. Middle-income students were partially covered by the first phase and fully covered by the second phase. Thus, those in the 2002-2004 cohorts saw dramatic loan reductions, while those from the 2005 and 2006 cohorts were given zero loans. Finally, higherincome students with need were unaffected by the first phase of the policy but covered under the second phase. Those in the 2005-2006 cohorts were given zero loans, while those in the 20022004 cohorts were treated in proportion to the fraction of their college careers that came after the no-loans policy was fully implemented in 2001-2002.

Figure 2 uses Anon $\mathrm{U}$ administrative data (discussed below) to compute the fraction of students in each cohort who applied for aid at any point in their careers, who were ever found to need financial aid, and who ever took out loans. While the former fraction remained relatively stable between the 1999 and 2006 cohorts, the fraction who took out loans decreased from 46 percent in 2002 to 23 percent in 2006 . Figure 3 provides a similar look at the dollar amounts, totaled over a student's time at Anon $\mathrm{U}$ and averaged over all students in the cohort with positive need (again, in any year). The typical amount of student loan debt at graduation among those with positive need fell from over $\$ 15,000$ in 1999 to $\$ 4,000$ in 2006 , a decrease of 67 percent. The sharp decline began with the 2002 cohort, the first cohort eligible for either portion of the no-loans program. The reduction in loans was more than offset by increases in grant aid, with the difference reflecting increasing average total need. ${ }^{13}$ Work awards actually fell slightly over the period. This decline, along with the continued presence of loans even after the no-loan policy was fully implemented, suggests that beneficiaries of this policy consumed some of their reduced self-help requirements by cutting back on campus work.

\footnotetext{
${ }^{13}$ The increase in total need primarily reflects increasing costs of attendance; average family contributions were approximately stable.
} 


\section{A Simple Model of Debt and Occupational Choice}

We suggested above that student debt should have very small effects on the post-college choices of unconstrained students, but that if individuals are debt averse or face credit constraints or other limits to the ability to borrow against future earnings, debt could have first-order effects on graduates' job choices. These claims derive from a two-period life-cycle model in which perperiod utility depends on both consumption and job amenities. Amenities might encompass the total hours required, the flexibility of the work schedule, the pleasantness of the work, or any other aspects of a job that make it appealing. Importantly for our empirical analysis, some people may derive amenity value from "public interest" work. Because amenities have no natural scale, we scale them in dollars of salary forgone on the upper envelope of the choice set a job offering amenity level $a$ will offer salary $\psi-a$.

Graduates start with student debt $d$ and work for two periods. Per-period utility depends on consumption $c_{t}$, and job amenities $a_{t}, u^{t}=u^{t}\left(c_{t}, a_{t}\right)$, where $t$ indexes periods and $u^{t}$ has positive first partial derivatives and negative second partial derivatives. The unconstrained individual maximizes lifetime utility

$$
\mathrm{U}\left(c_{1}, a_{1}, c_{2}, a_{2}\right)=u^{1}\left(c_{1}, a_{1}\right)+(1+\delta)^{-1} u^{2}\left(c_{2}, a_{2}\right)
$$

subject to the lifetime budget constraint,

$$
c_{1}+(1+r)^{-1} c_{2} \leq \psi_{1}-a_{1}+(1+r)^{-1}\left(\psi_{2}-a_{2}\right)-d=y_{1}+(1+r)^{-1} y_{2}-d,
$$

where $\delta$ is the discount rate, $r$ is the interest rate, $\psi_{1}$ and $\psi_{2}$ are potential earnings in periods 1 and 2 , respectively, and $y_{1}$ and $y_{2}$ are actual earnings.

With this setup, debt merely reduces lifetime income, and has solely income effects.

These are of order $d / Y$, where $Y=\psi_{1}+(1+r)^{-1} \psi_{2}$ is the present value of lifetime full income. A typical value for $d$ is around $\$ 20,000$, while $y_{1}+(1+r)^{-1} y_{2}$ averages around $\$ 1,500,000$ for 
college graduates, so $d / Y$ is not much above 1 percent. ${ }^{14}$ Even a relatively low-paid occupation like teaching yields lifetime earnings around $\$ 1,100,000$, implying $d / Y$ below 2 percent. Anon $\mathrm{U}$ graduates have less debt and much higher earnings, on average, than do typical college graduates, implying even smaller values of $d / Y .{ }^{15}$ Consequently, we expect that income effects of debt are very small for life-cycle consumers who can freely borrow and save.

Student debt can have important effects in the presence of constraints that limit agents' borrowing. The debt position at the end of period 1 is $D=d+c_{1}-y_{1}=d+c_{1}+a_{1}-\psi_{1}$. A binding upper bound, $D^{*}$, distorts intertemporal optimization, driving a wedge between marginal utility in periods 1 and period 2. The agent will choose lower values of both consumption and amenities in period 1, and higher period-1 earnings, than she would have chosen otherwise. The magnitude of the distortion depends on $D^{*}-d$, so if $D^{*}$ is low enough increases in $d$ reduce $c_{1}$ and $a_{1}$ and increase $y_{1}{ }^{16}$

Credit constraints are not the only possible source of debt effects on intertemporal optimization. Debt aversion - a negative effect of debt held at period 1 on lifetime utility that is independent of the level of consumption or amenities in each period - can generate a similar wedge between period-1 and period-2 marginal utility, with similarly distorting effects on career

\footnotetext{
${ }^{14}$ The debt figure derives from the authors' calculations from the National Postsecondary Student Aid Survey of 2003-2004 (Cominole et al. 2006). The lifetime earnings figure is the mean present discounted value and is computed from cross-sectional data on individuals aged 25-65 from the 2003 and 2004 March Current Population Surveys, assuming a real interest rate of 3.5\% (Moore et al. 2004) and productivity growth of $1.5 \%$.

${ }^{15} \mathrm{We}$ do not have data on the full earnings profile of Anon U graduates. But we can compare the earnings of typical young college graduates to the distribution in our data. In the 2002 and 2003 March CPS data, the average annual earnings of 21-25-year-old college graduates who worked at least 45 weeks were $\$ 30,000$. This corresponds approximately to the 9 th percentile salary among Anon U graduates who reported starting salaries in the exit survey from which our data are drawn.

${ }^{16}$ In our simple model, in which period-2 utility depends on period-1 choices only through the lifetime budget constraint, credit constraints increase $a_{2}$ and $c_{2}$ and reduce $y_{2}$. This result might not hold in a model that incorporates state-dependent preferences (to capture the intuition that people can become accustomed to certain consumption levels or to certain types of jobs). Much depends on the degree to which the agent can anticipate the effect of period-1 choices on her period-2 utility function. Our empirical analysis focuses on debt effects on $\mathrm{y}_{1}$, which would be positive with binding credit constraints even if preferences are state-dependent.
} 
choices. Below, we provide indirect evidence that helps to distinguish between credit constraint and debt aversion explanations for debt effects. ${ }^{17}$

\section{Estimation Strategy}

Our goal is to identify the effect of student debt on various outcomes, both during college and after graduation. We are interested in whether debt causes new graduates to make different choices than they would have had they reached the same decision point without debt. The Anon U reform, then, provides just the right counterfactual: students with financial need in later cohorts were given enough grant aid to meet that need without resorting to student loans. A comparison with otherwise-identical students from earlier cohorts can identify the loan effect of interest, provided that pure time effects are adequately addressed.

The most straightforward way to implement this comparison is as a difference-indifferences (DID) analysis, comparing the between-cohort change in mean outcomes among financial aid recipients with the change among students not receiving aid. Recipients were "treated" by the no-loans policy if they were in later cohorts but not if they were in earlier cohorts. Students who did not need financial aid should not have been affected by the policy regardless of their cohort, and can therefore be used to control for business cycle and other time effects. The effect of debt on an outcome variable $y$ can be computed as a Wald estimator, dividing the difference-in-differences in $y$ by that in debt.

The DID strategy has several important shortcomings. First, there may have been changes in the relative characteristics of aid recipients over time, not least because the rising cost of attending Anon U shifted families who would not previously have needed aid into the aid-

\footnotetext{
${ }^{17}$ A final potential violation of the life cycle model is uncertainty about period-2 earnings (i.e., about $\psi_{2}$ ). This may induce precautionary savings in period 1. Absent other violations, however, preexisting debt will continue to have only an income effect, which will remain small if $d$ is small relative to even a low realization of $\psi_{2}$.
} 
recipient category. Failure to control for this will result in a biased estimate of the aid effect.

Second, the DID estimator does not exploit variation in the intensity of treatment, either across or within cohorts. Students with very little financial need would have taken few loans in any case, so were not much affected by the no-loans policy, while those with greater need got larger benefits. Finally, the DID strategy cannot accommodate the partially-treated 2002-2004 cohorts. In the rest of this section, we develop a regression-based version of the DID/Wald estimator that allows us to control for changing student characteristics and to exploit variation in treatment that cannot be captured in a simple DID/Wald framework. This leads us to our primary specification, which combines instrumental variables - using simulated loan offers as instruments for the actual debt level to exploit only policy-induced variation in debt - with a "control function" specification that uses data on family financial circumstances to absorb potentially confounding variation in family background.

The DID-based Wald estimator can be seen as an IV estimate of the following equation:

$$
y_{i c}=\alpha+\text { post }_{c} \delta+\text { need }_{i} \gamma+d_{i c} \beta+e_{i c}
$$

where $y_{i c}$ is the outcome for student $i$ from cohort $c$, post $_{c}$ is an indicator for whether the student comes from a treated cohort; need $_{i}$ is an indicator for whether the student has financial aid, and $d_{i c}$ is the student's level of debt. The interaction of the two indicator variables, post ${ }_{c}^{*}$ need , serves as an instrument for $d_{i c}$.

To convert this to a richer specification, we need a more detailed measure of "treatment" than the simple post $_{c}{ }^{*}$ need ${ }_{i}$ interaction. Let $d_{i c}{ }^{99}$ be the loan that the student would have been offered had her aid package been calculated according to the formula that applied to the preprogram 1999 cohort. As a result of the program change, she was instead offered $d_{i c}{ }^{*}$. The treatment, then, is the difference between these, $d_{i c}{ }^{*}-d_{i c}{ }^{99}$. 
Note that $d_{i c}{ }^{99}$ is a deterministic function of the student's expected family contribution, $d_{i c}{ }^{99}=g^{99}\left(E F C_{i c}\right)$. For any single cohort $c, d_{i c}{ }^{*}=g^{c}\left(E F C_{i c}\right)$ is another deterministic function, though the shape of this function varies substantially with $c$. For $c \geq 2005, g^{c}(E F C)=d_{i c}^{*} \equiv 0$, while for earlier cohorts $g^{c}(E F C)$ more closely resembles $g^{99}(E F C)$ (particularly for non-lowincome families). The continuous-treatment analogue to the need $_{i}$ control in (1) is a flexible control for the effect of the expected family contribution on outcomes, $f\left(E F C_{i c}\right)$. We also generalize the post $_{c}$ dummy to a series of cohort dummies. Our primary estimating equation is thus:

$$
y_{i c}=\delta_{c}+f\left(E F C_{i c}\right)+d_{i c} \beta+e_{i c}
$$

with first stage equation

$$
d_{i c}=\theta_{c}+h\left(E F C_{i c}\right)+\left(d_{i c}{ }^{99}-d_{i c}{ }^{*}\right) \pi+\mathrm{v}_{i c} .
$$

Note that if the $f()$ and $h()$ functions are sufficiently flexibly parameterized, they will absorb all of the variation in $d_{i c}{ }^{99}$, which does not vary across students with the same expected family contributions. ${ }^{18}$ Thus, (3) can be equivalently written to use the student's own offered loan, $d_{i c}{ }^{*}$, as the instrument, and indeed we do this in our empirical implementation. ${ }^{19}$ Within any single cohort, $d_{i c}{ }^{*}$ would be absorbed by a sufficiently flexible $h()$ function, but with data pooling multiple cohorts a single $h()$ function cannot absorb the variation in $d_{i c}{ }^{*}$ among students in different cohorts with the same $E F C_{i c}$. Thus, it is only the cross-cohort variation in the $g^{c}()$ function - deriving from the Anon $U$ reform - that identifies the debt effect in (2). The central identifying assumption of our strategy is that the direct effect of family characteristics (or at least that operating through the $E F C_{i c}$ variable) on outcomes is constant over time.

\footnotetext{
18 Recall that $d_{i c}^{99}$ is what each student would have been offered in loans under the pre-program formula.

${ }^{19}$ We have also performed our analysis using $d_{i c}{ }^{99}-d_{i c}{ }^{*}$ as the instrument. This yields very similar estimates.
} 
Granting this assumption - to which we return later - our IV strategy should eliminate two possible sources of bias that would arise in simple OLS estimates of the effect of debt on outcomes. The first and most important is omitted variables. Most of the variation in student debt - and all of the variation in offered debt within a single cohort - derives from differences in families' financial resources. Family background is likely to have strong effects on academic and employment outcomes. If it is excluded from the estimating equation, both $d_{i c}$ and $d_{i c}{ }^{*}$ will be correlated with the error term. The inclusion of a flexible control function in the expected family contribution in our IV specification should eliminate the resulting bias since, as noted above, the offered loan is a deterministic function of the $E F C$. The possibility that $E F C_{i c}$ does not capture all dimensions of family background does not present a problem: So long as the projection of other family background characteristics onto the expected family contribution is constant over time, these characteristics will be uncorrelated with $d_{i c}{ }^{*}$ conditional on $E F C_{i c .}{ }^{20}$

A second possible source of bias is reverse causality. Empirically, there is a fair amount of variation in actual loans that is unexplained by the loan offer. This variation may reflect differences in tastes or in expectations about future earnings. In particular, those who expect high future earnings (i.e., have a high $e_{i c}$ when $y_{i c}$ is earnings) should consume more in college, and may take out more debt to finance this. This will bias an OLS estimate of $\beta$ from equation (2) upward, but this bias is eliminated in the instrumental variables estimate. ${ }^{21}$

We construct $d_{i c}{ }^{*}$ by applying the Anon U aid formula for the student's cohort to the observed expected family contribution variable. By the argument above, this is uncorrelated

\footnotetext{
${ }^{20}$ This strategy can be seen as a propensity score estimator, albeit with a continuous treatment variable, as flexible controls for $E F C_{i}$ absorb the endogeneity in $d_{i c}{ }^{*}$.

${ }^{21}$ In practice, there is some evidence that the financial aid office occasionally deviates from its formula in response to student requests, particularly when Anon $U$ is in competition with other colleges for a particular student. For our purposes, the "offered loan" is that indicated by the formula, even if in practice a different offer is made. This avoids any endogeneity of the negotiated aid package.
} 
with the residual component of family background, so long as $f()$ and $h()$ are sufficiently flexible. We model each as a cubic polynomial. To guard against the possibility that this fails to fully capture the variation used in the loan assignment, we control for the total financial need and, in some specifications, for the loan that would have been offered had the student been in the 1999 or the 2002 cohort (i.e., $d_{i c}{ }^{99}$ and ${d_{i c}}^{02}$ ). With these controls, the debt effect is identified solely from across-cohort variation among students who would have been offered the same aid package had they been in the same cohort.

Our identifying assumption would be violated if there were differential underlying trends in the employment outcomes of students receiving and not receiving financial aid. One possible source of such differential trends might be changes in the composition of the Anon $U$ aid population. In some specifications, we include controls for several non-aid student characteristics: indicators for whether the student was a legacy (i.e., had parents who attended Anon U), the first in the family to attend college, or a recruited athlete; a cubic in family income; and a full set of indicators for the academic and non-academic ratings given to the student's admissions application. These additional controls have essentially no effect on our estimates. We also report specifications that allow for changes in the returns to student characteristics over time by including unrestricted interactions of students' SAT scores - indicators of ability that are correlated with financial need - with cohort indicators. This, too, has no effect on the results.

A final issue is the possibility of sample selection. The Anon $U$ policy was well publicized, and some of the cohorts used in our analyses entered Anon $U$ after the policy was announced. If students made college choices on the basis of the policy, this could induce selection bias in our analysis. Linsenmeier et al. (2006) find evidence that the policy increased Anon U's yield from admitted students - the fraction who chose to matriculate - in the cohorts 
that matriculated shortly after the announcement of the first policy change. This effect is quite small, amounting to approximately 30 students per cohort. Sample selection of this sort is unlikely to bias our results. As a validity test, however, below we present analyses that exclude students who entered Anon U after the full no-loans policy was announced as well as all lowincome students. The loan effect is then identified from non-low income students from the 20022004 cohorts, who were partially treated by the no-loans policy.

\section{Data}

Our data come from Anon U's administrative records, and describe students from the cohorts that entered between Fall 1995 and Fall 2002 and graduated, for the most part, between 1999 and 2006. ${ }^{22}$ We merge data from several independent databases, using identifiers that are common to all of Anon U's student records. ${ }^{23}$ The registrar's data include 9,287 students from the 1999-2006 classes. We have complete data on admissions qualifications, financial aid, and employment outcomes for 8,641 students. ${ }^{24}$

\section{A. Financial Aid Data}

Our key explanatory variables come from financial aid records. We observe the expected family contribution and the size and composition of the aid award. We convert all dollar figures to 2005 dollars. The aid data are in student-year format, while most of our analysis focuses on student-level records. We sum the student loans taken over all years that the student appears in

\footnotetext{
2291 percent of Anon U matriculants graduate within four years and 96 percent graduate within five years. We have found no evidence that the no-loans program influenced time-to-graduation.

${ }^{23}$ For confidentiality reasons, we were given data containing only an anonymized version of this ID number. The anonymization algorithm was the same in each database, however, permitting us to merge them.

${ }^{24} 70 \%$ of the missing observations are students who have not graduated, split approximately evenly between those who have dropped out and those who are still active (the latter overwhelmingly from the classes of 2005 and 2006).
} 
the aid data, and average the expected family contribution over the student's (first) four years of enrollment.

The financial aid formula specifies the loan that should have been offered to each student as a function of the difference between the cost of attendance and the expected family contribution. This formula does not always seem to be followed in the data, in part because some students negotiate changes to their initial awards and only the final amount is reported. We use the formula to simulate the loan that should have been offered to each student in each year, given her family's income and the computed expected family contribution.

Not all students apply for aid in every year. This complicates our analysis, as the expected family contribution is computed only for aid applicants. We assume that any student who did not apply for aid would not have been found to have need in any case. This implies that her expected family contribution is at least as high as the cost of attendance, and we impute this value. $^{25}$

Other details of our data construction are discussed in a Data Appendix that is available from the authors. In general, our decisions were made with an eye toward maximizing the comparability of the data across cohorts. This leads us to censor variables from some cohorts to match the censoring that may have occurred in other cohorts. For example, a family in the 1999 cohort whose contribution exceeded the cost of attendance might not have applied for aid. Because costs rose over time, a family with the same income in the 2005 cohort might have applied for and received aid. We censor this family's contribution at the 1999 cohort's real cost of attendance, to preserve the symmetry with our treatment of the non-applying family from the

\footnotetext{
${ }^{25}$ Some students who apply for aid have EFCs that are above the cost of attendance. We censor these at the lower level, and include dummy variables in our regressions for the number of years that the EFC was imputed or censored. Another complication arises because estimated costs vary with, for example, the distance between the student's home and Anon U. We use the modal cost in each year for all students.
} 
earlier cohort. ${ }^{26}$ Our loan simulation is based on this censored contribution, although results are robust to alternative censoring rules - e.g., using the actual costs as the censoring point - and to the use of uncensored data.

Table 1 presents estimates that relate the composition of the actual aid package, cumulated over all years of enrollment, with the simulated cumulative loan offer. Each specification includes controls for cohort (a full set of dummy variables), a cubic in the parental contribution, indicators for the number of years that the contribution is censored and the number of years that the student applied for aid, and the student's cumulative financial need. With such rich controls, the simulated loan coefficient is identified exclusively from the differential effects of across-cohort variation in the loan formula on students with different need levels. If our simulation perfectly captured offered loans and if all students perfectly complied with the "intended" treatment, the simulated loan effect on actual loans would be exactly one, that on actual grants exactly -1 , and the effects on other variables would be zero. In reality, the estimated effects on loans and grants are likely attenuated by imperfections in our simulation and by imperfect compliance.

Column 1 presents an analysis in which the dependent variable is the total debt incurred over a student's time at Anon U. While the simulated loan offer coefficient is significantly different from one, it is nevertheless large - the realized cumulative loan rises by about $\$ 0.77$ for each additional dollar of offered loans - and quite precisely measured. Columns 2 and 3 take as dependent variables the other components of the aid award. The estimated coefficient for grant aid (Column 2) is -0.90 . Again, this is significantly different from the theoretical effect of -1 , but

26 That is, for each student we assign $d_{i c}{ }^{*}=g_{c}\left[\min \left(E F C_{i c}, \operatorname{cost} 99\right)\right]$ where $\cos t 99$ was the cost of attending Anon U for the class of 1999. 
in practical terms the deviation is small. ${ }^{27}$ Column 3 presents an analysis of term-time student work. For each dollar of loan reduction, term-time earnings fall by 8 cents. ${ }^{28}$ Column 4 indicates that the simulated loan is weakly (but significantly) negatively associated with total aid, the sum of grants, work, and loans. As we control for need, and as Anon U always offers an aid package that meets total need, the negative point estimate indicates that take-up of aid packages is lower when these packages include more debt, perhaps because some students substitute additional parental contributions for offered loans.

\section{B. Other Data}

We create a variety of control variables and outcome measures from other administrative data sets. We draw from admissions data the student's SAT score and legacy status, the type of high school attended (public or private), and the numerical ratings given to the application. The registrar provided information about the major, minors, grade point average (GPA), and honors received. $^{29}$ Our richest outcome measures come from an "exit survey" conducted by the Office of Career Services during the week before graduation. The survey asks about plans during the next year, and students who have already obtained jobs are asked their occupations, industries, and annual salaries. Response rates are typically above 97 percent. Finally, the Development Office provided information on students' donations to the university's "annual giving" campaigns in the first several years after graduation. Anon U's solicitations start early, and

\footnotetext{
${ }^{27}$ The most likely explanation is that we do not capture adjustments made to the formula award on a caseby-case basis by financial aid staff.

${ }^{28}$ We do not observe actual earnings, but only the assumed earnings that were included in the final financial aid offer. Upon receipt of the original offer, which might have specified \$0 in loans and \$1500 in termtime earnings, students were permitted to negotiate alternative divisions of the "self help" component between loans and work. Our point estimate indicates that a student receiving a \$0/\$1500 initial award negotiated a final award that specified $\$ 120$ in debt, on average, and $\$ 1380$ in work.

${ }^{29}$ There are no double-majors at Anon U, and minors are permitted in only a limited number of fields that are (typically) not available as majors. The available minors include finance, public policy, various foreign languages and area studies, and elementary/secondary education.
} 
students are asked during their senior year to make pledges covering each of the next five years. We observe both pledges and actual gifts, though our ability to look several years beyond graduation is limited for the most recent classes. ${ }^{30}$

Table 2 presents comparisons of the observable characteristics of students from the 19992001 cohorts (nearly all of whom graduated before the no-loans program) and those from the 2005-2006 cohorts (who entered after full implementation). We distinguish between students with positive financial need, who would have been affected by the no-loans policy, and students without need, who would not. Columns (1) and (2) show the average characteristics of "noneed" and "need" students in the earlier cohorts, while columns (3) and (4) show the same groups in the later cohorts. Columns (5) and (6) show the change over time for each group, and column (7) shows the difference between these.

Students with need have lower average SAT scores than those without need, are less likely to be white, and are much less likely to have attended private high schools (although even so, a third of students with need attended such schools). There were few changes between the two cohorts in racial composition or the type of school attended. Elite college admissions became much more competitive over this period, however, and SAT scores rose dramatically in both the need and no-need subgroups.

The remaining rows of the table show financial characteristics, which we observe only for students who apply for financial aid and which are therefore shown only for students with need. Real family incomes of students with need rose about 8 percent between cohorts, and mean expected family contributions rose by a bit less than $\$ 900$. Average need rose by over $\$ 12,000$. This primarily reflects the increasing cost of attending Anon $U$ - tuition, fees, and

\footnotetext{
${ }^{30}$ Our alumni gift data were extracted in Fall 2006, so we do not observe gifts for the class of 2006, observe only one year of gifts for the class of 2005, and so on.
} 
room and board collectively rose by $\$ 12,122$ over this period. ${ }^{31}$ Despite the increase in need, average student loans fell dramatically, from $\$ 15,485$ in the 1999-2001 cohorts to less than $\$ 3,500$ in the 2005-6 cohorts. Some students without demonstrated need took loans as well, but the average amounts are quite small. ${ }^{32}$ The difference-in-differences estimate of the effect of the no-loans program on the total debt that students incur is $-\$ 11,389$.

Table 3 presents DID analyses of our primary outcome measures, grouped into “academic," "career," and "alumni gifts" categories. Aid recipients have lower GPAs and rates of honors receipt than non-aid recipients. GPAs rose for both groups of students in the later cohorts, with a slightly larger increase for aid recipients. There were no meaningful changes in honors receipt. Small effects on this outcome appear in our IV analyses below.

Our model suggests that in the presence of debt aversion or credit constraints debt will lead students to substitute toward higher-salary jobs with lower levels of job amenities, particularly in the years immediately after graduation when constraints are likely to be most binding. We find little relative change in aid recipients' propensities to plan employment or graduate school during the year after graduation, nor in the probability that they will have a job lined up as of graduation. There do appear to be shifts in the types of jobs that they take, however, as measured by the industry. We consider two groups of high-salary and two groups of low-salary industries. Our first group of high-salary industries includes consulting ${ }^{33}$, banking, and finance jobs, which collectively account for over half of Anon U students with jobs on graduation. Our second group adds to these a group of industries - like pharmaceuticals and

\footnotetext{
${ }^{31}$ The increase in costs may explain the increase in the family incomes of students with need (which amounts to about $\$ 6,000$ at the mean), as families whose expected contributions fell between the old and new tuition levels would have been judged to have need in the later period but not in the earlier period.

${ }^{32}$ We have been told that some students who apply for aid but are found not to have need are nevertheless offered token aid packages composed primarily of "self help." The decline in loans among no-need students may indicate that loans were removed from these packages when the no-loans policy was implemented.

${ }^{33} \mathrm{We}$ also include in this category individuals who listed other industries (e.g., health care) but reported "consulting" as their occupation.
} 
computer products and services - that also offer high mean salaries. On the low-salary side, we first consider the nonprofit, government, and education sectors (together 19 percent of our sample), then expand this to include other low-salary industries like publishing and architecture.

Aid recipients shifted out of industries with high average salaries and into lower-salary industries, while there was little change in the industry composition of jobs taken by students not on aid. While there was no relative decline in the share of aid recipients taking jobs in the consulting, investment banking, and finance sectors - the most prominent high-salary employers of Anon U graduates - there was a notable increase in the share taking jobs in the nonprofit, government, and education sectors. ${ }^{34}$ Consistent with this shift, we see that aid recipients' mean salaries did not increase at the rate seen among non-recipients. Effects of debt are most likely at the lower end of the salary distribution, and indeed we see that the fraction of non-aid students with salaries below $\$ 41,395$ (the $25^{\text {th }}$ percentile salary in our data) fell substantially while there was no corresponding drop among students on aid.

The last rows of the table show mean alumni pledges and gifts for the year immediately following graduation, when alumni are perhaps most likely to be financially constrained. We see significant increases in both pledges and gifts from aid recipients. The change for non-aidrecipients - who both pledge and give more than recipients in all cohorts - is smaller and not significant.

All of these changes are consistent with the presence of debt effects on students' career choices and on the constraints that they face after graduation. They can be readily converted into Wald estimators of the effect of student debt by dividing by the difference-in-differences in total loans, $-\$ 11,389$ (from Table 2). Estimates are shown in Column 8 of Table 3. They indicate that debt may slightly reduce grades, reduces the probability of taking a job in a low-paid sector,

\footnotetext{
${ }^{34}$ There is no clear pattern in the industries from which these students are drawn.
} 
substantially increases the mean salary for those students who have jobs, and somewhat reduces alumni gifts. These descriptive changes may be confounded, however, by changes in the characteristics of students who receive aid. In the next section, we present analyses that use the IV and control function strategies outlined above to obtain consistent individual-level estimates of the effect of debt on student outcomes.

\section{Results}

\section{A. Effects on Employment Outcomes}

Table 4 presents regression estimates of the effect of student debt (in $\$ 10,000$ s) on the employment outcomes from Table 3. Column 1 shows sample sizes; these are smaller for outcomes that are only available for students who have accepted jobs and who report annual salaries than for other outcomes. Columns 2 - 4 present OLS results, without any controls (column 2), with a cubic in the expected family contribution and a linear control for the total need (column 3), and with those controls plus a vector of other family background and academic quality controls (indicators for being a first-generation college student, a legacy at Anon U, or a recruited athlete, plus academic and non-academic admissions ratings and the simulated loan under the rules that applied to the 1999 and 2002 cohorts) in column $4 .^{35}$ The next three columns repeat these specifications but instrument for the observed loan with our simulated loan offer. The first stage coefficients in the three specifications are shown in the first row. As in Table 1, the coefficients suggest that the instrument is strongly related to the actual loan amount and that a dollar in simulated loans increases a student's actual debt by about 77 cents.

\footnotetext{
${ }^{35}$ Columns 2 and 3 also include controls for the number of years that the family contribution was censored or imputed. We present only linear probability models. Results are similar (though more difficult to interpret in IV specifications) when we instead use probit models.
} 
In the simplest specifications without controls, we estimate no effect of debt on the likelihood that an individual plans to attend graduate school and a statistically significant, positive effect on the likelihood of planning employment. ${ }^{36}$ When we add controls for family financial circumstances, the effect on whether the student plans employment is largely unaffected but that on whether the student plans to attend graduate school becomes significantly negative, suggesting that the original estimate was confounded by differences between students with and without financial need. Effects on both graduate school and employment decrease and become statistically insignificant (partly because standard errors rise substantially) in IV specifications although the point estimates indicate positive effects on employment and negative effects on graduate school. We similarly find no debt effects in IV specifications for the probability that a student has found a job by the time of the survey.

The next rows examine the distribution of accepted jobs across industries. We see little impact of debt on the probability that a student takes a job in the high-salary groups of industries. By contrast, we find negative, statistically significant effects of debt on employment in the lowsalary occupations. Specifically, in our preferred specifications in columns 6 and 7, we estimate that an extra $\$ 10,000$ in student debt reduces the likelihood that an individual will take a job in nonprofits, government, or education by about 5 to 6 percentage points. This is a large effect, particularly when compared with the approximately 17 percent baseline share of students going into these sectors. Further investigation (not reported in Table 4) indicates that this is driven primarily by the education sector: in the specification from Column $6, \$ 10,000$ in student debt

\footnotetext{
${ }^{36}$ The predicted effect on whether the student plans to attend graduate school is ambiguous, as loan payments can be deferred while a student is in school. Still, undergraduate loans may deter debt-averse students from taking on further debt for graduate school.
} 
reduces the probability of taking a job in education by 3.3 percentage points (standard error $0.20) .^{37}$

We next look at the impact of college loans on a student's actual starting salary. ${ }^{38}$ Our preferred specifications indicate that an additional $\$ 10,000$ in debt leads students to accept jobs that pay about $\$ 2,000$ (p-value $0.06-0.10$ ) more in annual salary, on average, and reduces the likelihood that the salary is below $\$ 41,395$ by about 6 percentage points ( $\mathrm{p}$-value 0.09 ).

Overall, it appears that college debt affects post-graduation employment decisions: students with more debt are less likely to accept jobs in low-paying industries and accept higherpaying jobs more generally. Both results are consistent with debt aversion or the presence of credit constraints. These effects on industry and starting salary are large. The current Stafford loan interest rate is 6.8 percent, suggesting that a $\$ 10,000$ loan paid off over ten years (the typical repayment period) would have annual payments of $\$ 1,380$. Our result thus implies that afterdebt-payment income rises with debt. This may be explained by taxes: with a 33 percent tax rate, our point estimates imply that after-tax earnings rise one-for-one with debt payments.

\section{B. Robustness}

Table 5 presents several alternative specifications - using different loan measures, instruments, samples, and control variables - meant to gauge the robustness of our employment, industry, and salary results. Column 1 repeats the estimates from Column 5 of Table 4 for

\footnotetext{
${ }^{37} 19 \%$ of Anon U students with education jobs teach in private schools; $26 \%$ work for Teach for America or for other similar organizations. Our samples are too small to distinguish effects of debt on the distribution of students within the education sector, but point estimates give no indication that either of these types of jobs accounts for the effect.

${ }^{38}$ We have examined the sum of the starting salary and the anticipated annual bonus, with qualitatively similar results. Only $42 \%$ of students with jobs report an expected bonus, however, and the survey form does not distinguish missing values from zeros. We have also explored imputing salaries for the $21 \%$ of students who have jobs but do not report their salaries, using observed salary responses from other students working for the same firms. Estimates using the imputed data are similar to those reported in Table 4, with similar standard errors once the variation introduced by the imputation is accounted for.
} 
several key outcomes. Column 2 adds to the endogenous debt measure the sum of any loans that students' parents have taken from Anon U, either via the PLUS program or from Anon U's unsubsidized parental loans office. ${ }^{39}$ This has little effect on the estimates.

Column 3 returns to the original specification of the endogenous variable, but forms the instrument from an alternative simulation that uses the aid formula that applied to the years that the student was actually in attendance rather than those that applied to the first four years after the student enrolled. This simulation is identical for the 96 percent of graduates who enrolled for four consecutive years and graduated on time, as well as for 0.3 percent who graduated early after enrolling for three consecutive years. It differs only for students who took time off before graduating or who spent more than four years at Anon U. Not surprisingly, the alternative instrument yields nearly identical results.

Column 4 excludes the 2005 and 2006 cohorts as well as all low-income students from the sample. One concern with the earlier results is that we include students who might have enrolled as a result of the program. Non-low-income students in the classes of 2002-2004 were grandfathered into the program after they had already enrolled at Anon U and so the program could not have affected their application and matriculation decisions. Estimated debt effects in this column are generally similar to those in our main specifications.

Finally, Column 5 includes in the specification interactions of the student's SAT score with a full set of cohort dummies. The macroeconomy weakened somewhat over our sample period, and this may have had differential effects on high- and low-ability students. This

\footnotetext{
${ }^{39}$ Our data on parental loans extend only through the end of the 2004-5 academic year. We thus exclude students from the 2006 cohort in this column.
} 
specification controls for this, at least to the extent that the SAT score proxies for ability.

Estimated debt effects are essentially unchanged. ${ }^{40}$

We have also explored specifications that allow debt effects to vary with students' predetermined characteristics. Debt seems to have the largest effect on the salaries and employment choices of high-SAT students with low financial need, though these estimates are imprecise. There does not seem to be any substantial variation of debt effects with gender. ${ }^{41}$

\section{Effects on Educational Outcomes at Anon U}

The estimates presented above indicate that debt reduces students' probabilities of taking low-salary jobs. It may also have effects on students' job qualifications. Students who are or expect to be more financially constrained may study more (if alternative activities are expensive) or less (if term-time employment tightens the time constraint) than those with more disposable funds. On the other hand, students anticipating a desire to obtain a high-paid job after graduation may make different choices while at Anon U. Thus, we also examine the effects of debt on students' academic performance.

Results are presented in Table 6. Specifications are parallel to those in Table 4. The first rows show effects on the student major, as measured by the broad academic division (social sciences, humanities, physical sciences, or engineering). OLS control function estimates seem to show that debt is associated with higher probabilities of majoring in the social sciences and humanities, at the expense of engineering. IV estimates without controls show the opposite

\footnotetext{
${ }^{40}$ Macroeconomic changes may have induced changes in the relative behavior of aid- and non-aid students over time that do not derive from ability differences between the two groups. We have explored specifications that allow for EFC-time interactions, but given the gradual implementation of the program indicated in Figure 1, this absorbs most of the variation in our instrument and leads to extremely imprecise IV estimates. The structure of the Anon U program evidently does not allow us to weaken our identifying assumption this much.

${ }^{41}$ There are too few black and Hispanic students at Anon U to permit meaningful subgroup analysis.
} 
effects. When we combine the two strategies in columns 6 and 7, both effects become insignificant, although the point estimates indicate a non-trivial shift toward engineering.

The next rows show effects on specific majors. Debt seems to have a positive, marginally significant, effect on the probability of choosing an economics or engineering major, both of which are associated with access to high-salary jobs. It has a negative, imprecisely estimated, effect on choosing a major from within a group that might be categorized as nonremunerative. ${ }^{42}$ We find no indication of debt effects on academic minors, including the public policy and teaching certificates that seem most closely associated with the employment outcomes seen earlier.

The final rows show models for students' GPAs and for whether they graduate with honors. In our basic IV control function specification (column 5), debt seems to have large negative effects on each. However, when we control for students' entering academic credentials in column 6 , these effects shrink substantially and become indistinguishable from zero.

On the whole, debt appears to have small effects on the choice of major, at most inducing a small shift toward majors that might be seen as oriented toward employment and away from “consumption"-type majors, and zero or small negative effects on academic performance. There is no indication that the debt-induced shift toward higher-paid jobs might derive from a positive effect on students' employability. Thus, it seems reasonable to interpret the earlier estimates of debt effects on employment outcomes as reflecting students' preferences rather than constraints imposed by their academic performance.

\footnotetext{
${ }^{42}$ We classify all of the humanities, history, history of science, anthropology, political science, and sociology as "non-remunerative." We include in the "economics or engineering" category students with other majors who earn minors in finance, many of whom are bound for financial industry jobs.
} 


\section{Effects on Alumni Giving}

Finally, we consider the effect of student loans on annual alumni giving to Anon U. There are two reasons to expect effects of debt on alumni gifts. First, if students perceive debt relief as a gift from the University, increased donations may be a way to show their gratitude. Second, if debt causes students to be constrained after college, it will also increase the shadow cost of contributions and therefore reduce their level (at least during the constrained years). ${ }^{43}$ Data on pledges can also inform our analysis. Students approaching graduation seem likely to be able to anticipate their desire to give to the university, but may not anticipate the constraints that they will face in the "real world." We compare actual gifts with those pledged during the senior year, when the Anon U Development Office asks students to commit to their annual gifts for the next five years. ${ }^{44}$ Differences between what students pledge and what they actually give can be seen as evidence of unanticipated financial difficulty (or bounty).

We present estimated effects in Table 7 for five measures of alumni gifts. Each specification uses the IV-control function specification from Column 6 of Tables 4 and 6 . In Column 2, the dependent variable is an indicator for whether the student pledged a donation. In Column 3, it is an indicator for actually donating. Columns 4 and 5 examine the amount of the pledge or donation, assigning zero for students who did not participate. Finally, Column 6 examines an indicator for whether or not the gift fell short of the pledge (which occurs about one quarter of the time in the first year after graduation). The rows of the table examine gifts in different years: the first row presents results for gifts during the first year after graduation (62

\footnotetext{
${ }^{43}$ Anon $U$ has a large endowment, so the primary cost to it of a deferred contribution is foregone investment earnings. Like other elite universities, Anon U typically earns higher returns than most individual investors. Still, even if a potential donor fully internalizes the effect on Anon U of deferring a contribution, the implied interest rate is most likely lower than that available to her from other lenders.

${ }^{44}$ Conversations with Anon U students suggest that peer pressure is an important motivation for pledges. We see no reason to expect, however, that the importance of peer pressure should change with the introduction of the no-loans policy.
} 
percent participation, unconditional mean gift \$21) and for pledges concerning gifts during that year; the second row results for gifts during the second year (64 percent participation, mean gift $\$ 27)$; etc. Note that the sample sizes are notably smaller in the bottom rows. We have data only through the summer of 2006, so cannot observe gifts during the $4^{\text {th }}$ year for the class of $2003,3^{\text {rd }}$ year for the class of $2004,2^{\text {nd }}$ year for the class of 2005 , or any year for the class of $2006{ }^{45}$

The results suggest that college debt has no effect on whether students pledge donations (column 2). Debt does appear to have negative effects on whether students actually give (on the order of 3 percentage points per $\$ 10,000$ in loans), though these are only marginally statistically significant ( $\mathrm{p}$-value 0.07 for year $1,0.13$ for year 2 ). We see similar patterns for amounts: effects on pledges are small (except in year 4, for which the sample includes only the classes through 2002), while there are somewhat larger effects on actual gifts. Column 6 indicates that debt has significant positive effects on the probability of falling short on a pledge, at least in the first year after graduation.

We interpret Table 7 as providing further, indirect evidence that students do not follow the life-cycle model in the first years after college graduation. The effects are small in absolute magnitude but are reasonably large relative to the average gift from a recent graduate. ${ }^{46}$ Moreover, the estimates of larger effects on actual gifts than on pledges and of negative effects of debt on the probability of fulfilling a pledge offers suggestive evidence that can help to distinguish credit constraints from debt aversion as explanations for the failure of the life-cycle model: this result suggests that recent graduates are surprised by the effect that debt has on

\footnotetext{
${ }^{45}$ The class of 2005 is the first fully-treated class. Thus, estimates for year 2 and beyond are identified only from partially-treated students.

${ }^{46}$ Anon U's officials may be interested in whether the no-loans program will pay for itself through increased donations. This depends strongly on the growth rate of debt effects as graduates age. Median nominal contributions from the class of 1985 over the first 20 years were 23.5 times the four-year median for that class. If debt effects grow at the same rate, the total effect of $\$ 10,000$ in debt reduction will be to increase donations by $\$ 318$, only a fraction of the cost of replacing $\$ 10,000$ in loans with grants. Of course, donations are highly skewed, and a single large donation could overturn this calculation, as could increases in mean donations in the years beyond 20.
} 
them, a reaction that seems more consistent with unexpected credit constraints than with foreseeable debt aversion.

\section{Generalizability of Findings}

An important question concerns the generalizability of our results. Our analysis derives from a sample of students at a particular school, and our results might not extend to typical college students. There is at least good reason, however, to suspect that debt effects should be larger for typical students than for Anon $\mathrm{U}$ graduates. Table 8 presents comparisons of academic and financial characteristics of Anon U students from the 1999-2001 cohorts with those of nationally-representative samples of aid recipients in various categories. ${ }^{47}$ We consider three comparison samples of institutions. The narrowest category consists of private four-year institutions that are classified (according to the Carnegie taxonomy) as Research I and II, $\mathrm{PhD}$ granting I and II, comprehensive I and II, or liberal arts I and II. ${ }^{48}$ Column 3 adds 4 -year public institutions in the same Carnegie classifications. Finally, Column 4 includes students from all 4year schools. Students receiving need-based financial aid represent approximately 40 percent of Anon U's seniors, 67 percent of 18-24-year-old seniors at comparable private institutions, and 48 percent of students at comparable public and private institutions or at all four-year institutions.

Anon $\mathrm{U}$ is one of the most selective schools in the country, and in an academic sense its students are clearly unrepresentative. They have much higher SAT scores and are more likely to have attended private high schools than their counterparts in any of the comparison samples. Aid recipients at Anon $\mathrm{U}$ are wealthier than students on aid nationwide, but generally are reasonably

\footnotetext{
${ }^{47}$ The comparison samples are drawn from the 2000 NPSAS (Riccobono et al. 2002). We restrict our attention to dependent students aged 18-24 who were enrolled full-time in 1999-2000 and graduated in that year. Because the NPSAS is a point-in-time survey rather than a panel, we select in both the NPSAS and the Anon U data on receiving aid during the senior year. Characteristics of Anon $U$ students from later cohorts are similar in all dimensions except average student loans.

${ }^{48}$ Anon U is a Carnegie Research I school.
} 
comparable to aid recipients at private colleges. For example, the mean family income among students receiving need-based financial aid at Anon U was approximately $\$ 93,000$ (in 2005 dollars), whereas private college aid recipients had average family incomes of $\$ 84,000$ and aid recipients overall had average incomes of $\$ 74,000$. Approximately 30 percent of Anon $U$ aid recipients and 36 percent of those at comparable private schools have family incomes below $\$ 60,000$ (which corresponds roughly to the upper threshold for the "middle income" category in Figure 1). Aid recipients at Anon $U$ thus come from somewhat wealthier families than do those at less selective institutions, though the differences are not large.

Table 8 also shows statistics for student debt. Students receiving financial aid at Anon U before the no-loans program incurred an average of $\$ 16,597$ in educational debt over their college careers. Cumulative debt levels were nearly double that amount in comparable private colleges and universities and slightly less for graduates from all institutions.

Table 8 offers several reasons to expect that debt effects will be at least as large for typical students as for Anon U students. First, debt levels at Anon U are relatively low, and Anon $\mathrm{U}$ students are for that reason less likely to reach any given debt ceiling than are students from other schools. Second, Anon U students earn higher salaries after graduation than typical college graduates. An analysis of Current Population Survey data indicates that college graduates aged 21-24 and employed full-time throughout 2001 had mean salaries of \$36,800 (in 2005 dollars), far below the average of around \$50,000 for employed Anon U students (Table 3). Even if access to credit is independent of earnings, high salaries might reduce the utility cost of constrained consumption and thereby reduce the effect of debt on job choices. ${ }^{49}$ Third, Anon U students' parents have relatively high incomes, and may be able to offer intra-family loans that

\footnotetext{
${ }^{49}$ Desired borrowing depends on the ratio of permanent income to present income. This ratio is plausibly higher for Anon U students than for others.
} 
permit consumption smoothing without employment distortions. Finally, Anon U's students' higher SAT scores may indicate that they make better decisions, which again might reduce the effect of debt on choices.

\section{Conclusion}

There is widespread concern about the level of debt incurred by those acquiring a postsecondary education. Among the concerns is that the debt burden distorts graduates' postschooling decisions. However, the basis for such concerns is unclear. In standard economic models, with well-functioning credit markets, student debt should have only income effects on career and consumption decisions of life-cycle optimizers; since debt composes such a small portion of an average college graduate's lifetime earnings, these effects should be quite small. In this view, debt is the ideal mechanism for financing college education, as it permits a student to internalize the full costs of her investment decisions. There is no reason to think that high levels of student debt represent a market failure that warrants intervention.

In the standard model, Anon U's no-loan program should have had essentially no effect on its beneficiaries' career choices. This is not borne out by the data. When students were relieved from the need to incur debt, they shifted toward lower-salary jobs in public service industries. The point estimates indicate that changes in employment choices were large enough to entirely offset the effect of student debt on after-tax, after-loan-payment earnings in the first years after graduation. The standard model cannot rationalize a response of this magnitude.

Our paper adds to an existing body of evidence that consumer behavior is poorly characterized by the life-cycle model. The most plausible explanations for our results are that recent college graduates are averse to holding debt or that they face constraints on their ability to borrow against future earnings, either of which could lead to non-trivial effects of student debt 
on occupational choices. Unfortunately, we have limited ability to distinguish between these competing explanations. We find suggestive evidence that debt reduces students' donations to Anon $U$ in the years after they graduate and increases the likelihood that a graduate will default on a pledge made during her senior year, indicating that seniors do not fully anticipate the effects of debt. We believe this finding is more consistent with credit constraints than debt aversion, as it seems likely that seniors will be able to anticipate their future debt aversion and less likely that they will correctly forecast constraints on their ability to borrow. This conclusion is necessarily tentative, however.

There are many outstanding questions about the role of debt in decision-making that we do not address. We have no direct evidence, for example, that student loans crowd out other forms of borrowing. If student debt prevents graduates from obtaining home mortgages - which are typically taken out several years after college graduation - effects on utility could be larger than those captured by our employment analyses. Another important avenue for further investigation concerns the effect of post-graduation credit constraints on pre-college decisions. If young people anticipate that taking on debt will constrain their consumption choices early in their careers, even free access to student loans will not lead to optimal educational investment. Clearly, optimal design of college financing mechanisms will require a deeper understanding of the role of debt in decision-making and a better characterization of the availability of affordable debt to young people today, both during college and beyond. 


\section{References}

Baum, Sandy and Marie O'Malley, "College on Credit: How Borrowers Perceive their Education Debt." Nellie Mae Corporation Report, February 6, 2003.

Bowen, William G., Martin A. Kurzweil, and Eugene M. Tobin. Equity and Excellence in American Higher Education (Charlottesville, VA: University of Virginia Press, 2005).

Burdman, Pamela. "The Student Debt Dilemma: Debt Aversion as a Barrier to College Access." U.C. Berkeley Center for Studies in Higher Education Research \& Occasional Paper Series, CSHE.13.05 (October 2005).

Carneiro, Pedro and James J. Heckman, "The Evidence on Credit Constraints in Post-Secondary Schooling." The Economic Journal, vol. 112 (October 2002): 989-1018.

Callender, Claire and Jon Jackson. "Fear of Debt and Higher Education Participation." London South Bank University Families \& Social Capital ESRC Research Group Working Paper No. 9 (November 2004).

Cameron, Stephen V. and Christopher Taber. "Estimation of Educational Borrowing Constraints Using Returns to Schooling." Journal of Political Economy, vol. 112, no. 1, pt. 1 (February 2004): 132-182.

Chiteji, Ngina S. "To Have and To Hold: Young Adults and Credit Markets." Manuscript, Skidmore College (January 2007).

Cominole, Melissa, Peter Siegel, Kristin Dudley, David Roe, Theresa Gilligan, and James Griffith. "2004 National Postsecondary Student Aid Study (NPSAS:04) Full-Scale Methodology Report." National Center for Education Statistics Technical Report NCES 2006-180 (June 2006).

Ellwood, David T. and Thomas J. Kane. "Who is Getting a College Education? Family Background and the Growing Gaps in Enrollment." In Sheldon Danziger and Jane Waldfogel, eds., Securing the Future: Investing in Children from Birth to College (New York: Russell Sage Foundation, 2000).

Feldstein, Martin. "College Scholarship Rules and Private Saving." American Economic Review, vol. 85, no. 3 (June 1995): 552-566.

Field, Erica M. "Educational Debt Burden and Career Choice: Evidence from a Financial Aid Experiment at NYU Law School." Manuscript, Harvard University (March 2005).

Gladieux, Lawrence E. and Arthur M. Hauptman. The College Aid Quandary: Access, Quality, and the Federal Role (Washington, D.C. and New York: The Brookings Institution and The College Board, 1995)

Gross, David B. and Nicholas S. Souleles. "Do Liquidity Constraints and Interest Rates Matter for Consumer Behavior? Evidence from Credit Card Data." Quarterly Journal of Economics, vol. 117, no. 1 (February 2002): 149-185.

Heckman, James J. and Lance Lochner. "Rethinking Education and Training Policy: Understanding the Sources of Skill Formation in a Modern Economy." In Sheldon 
Danziger and Jane Waldfogel, eds., Securing the Future: Investing in Children from Birth to College (New York: Russell Sage Foundation, 2000).

Hill, Catharine B. and Gordon C. Winston. "How Scarce are High-Ability, Low-Income Students?" In Michael S. McPherson and Morton Owen Schapiro, eds., College Access: Opportunity or Privilege? (New York: The College Board, 2006): 75-102.

Johnson, David S., Jonathan A. Parker, and Nicholas S. Souleles. "Household Expenditure and the Income Tax Rebates of 2001." American Economic Review, vol. 96, no. 5 (December 2006): 1589-1610.

Kamenetz, Anya. Generation Debt: Why Now is a Terrible Time to be Young (Riverhead Books: New York, 2006).

Linsenmeier, David, Harvey Rosen, and Cecilia Elena Rouse. "Financial Aid Packages and College Enrollment Decisions: An Econometric Case Study." Review of Economics and Statistics, vol. 88, no. 1 (February 2006): 126-145.

Loft, John D., John A. Riccobono, Roy W. Whitmore, Robert A. Fitzgerald, and Lutz K. Berkner. "Methodology Report for the National Postsecondary Student Aid Study, 199293." National Center for Education Statistics Technical Report NCES 95-211 (October 1995).

Minicozzi, Alexandra. "The Short Term Effect of Educational Debt on Job Decisions." Economics of Education Review, vol. 24, no. 4 (August 2005): 417-430.

Mishel, Lawrence, Jared Bernstein, and Sylvia Allegretto. The State of Working America 2006/2007. (Economic Policy Institute/ILR Press: Ithaca, New York, 2007).

Moore, Mark A., Anthony E. Boardman, Aidan R. Vining, David L. Weimer, and David H. Greenberg. "'Just Give Me a Number!' Practical Values for the Social Discount Rate." Journal of Policy Analysis and Management, vol. 23, no. 4 (2004): 789-812.

Riccobono, John A., Melissa B. Cominole, Peter H. Siegel, Tim J. Gabel, Michael W. Link, Lutz K. Berkner, and Andrew G. Malizio. "National Postsecondary Student Aid Study 19992000 (NPSAS:2000) Methodology Report." National Center for Education Statistics Technical Report NCES 2002-152 (June 2002).

Snyder, Thomas D., Alexandra G. Tan, and Charlene M. Hoffman. Digest of Education Statistics, 2005. (Washington, D.C.: National Center for Education Statistics, 2006).

Souleles, Nicholas S. "The Response of Household Consumption to Income Tax Refunds." American Economic Review, vol. 89, no. 4 (September, 1999): 947-958.

Stinebrickner, Todd R. and Ralph Stinebrickner. "Credit Constraints and College Attrition." Unpublished manuscript, University of Western Ontario (undated).

Trends in College Pricing, The College Board, 2005, spreadsheet.

Warner, John T. and Saul Pleeter. "The Personal Discount Rate: Evidence from Military Downsizing Programs." American Economic Review, vol. 91, no. 1 (March 2001): 3353. 


\section{Figure 1.}

\section{Expected student loans, by cohort and family income}

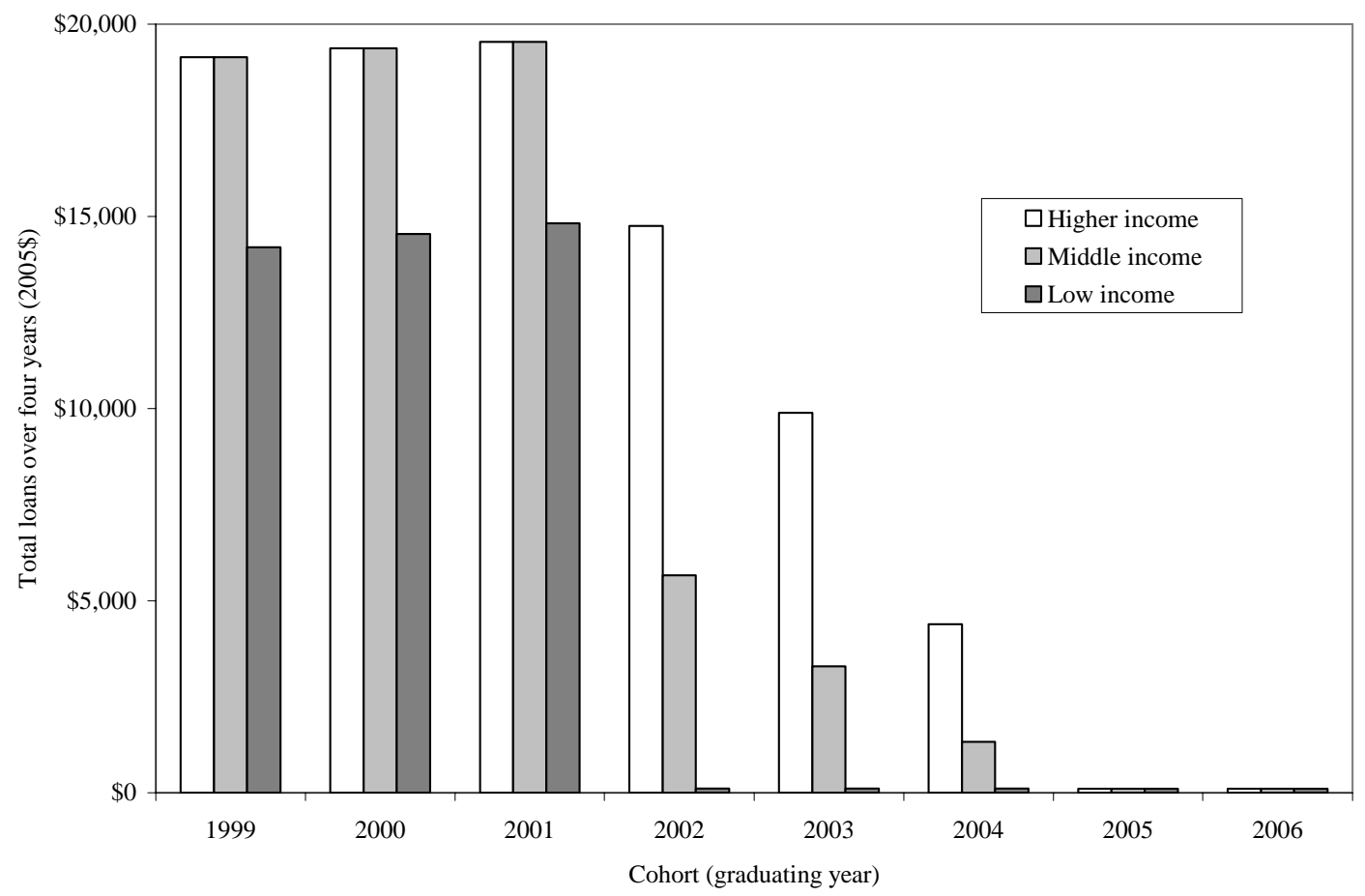

Notes: Figure shows the loans indicated by the Anon. U. formula for students from three illustrative families who attend for four consecutive years, by cohort. The "higher income" family has nominal income $\$ 120,000$ in each year but qualifies for $\$ 10,000$ in aid. The "middle income" family has nominal income $\$ 48,000$ and calculated parental contribution $\$ 4,000$ in each year. The "low income" family has nominal income $\$ 38,000$ and calculated parental contribution $\$ 1,000$ in each year. 
Figure 2.

Fraction of students ever applying for and receiving aid, by graduating cohort

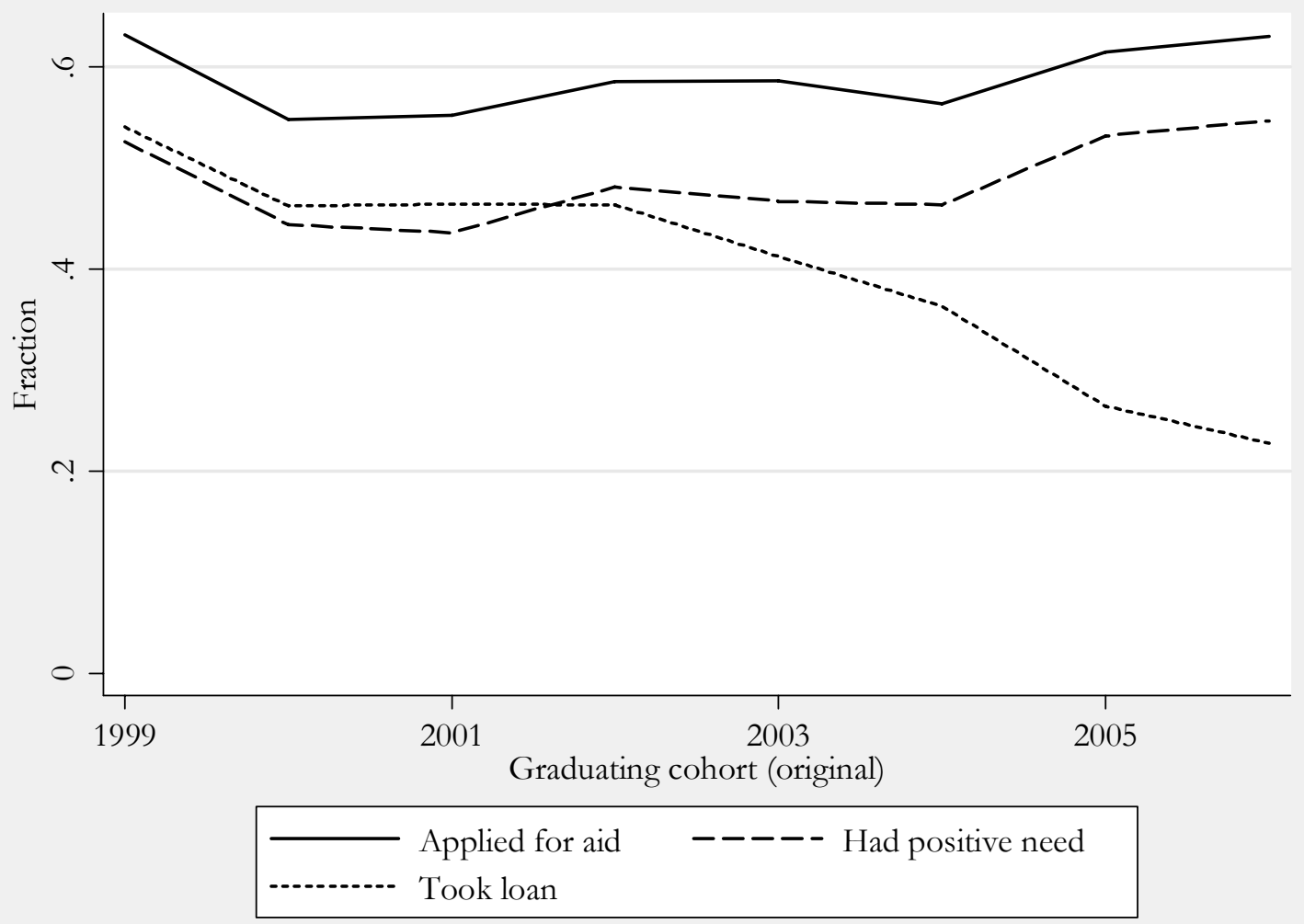


Figure 3.

Mean cumulative need, loans, and grants for students with positive need, by graduating cohort

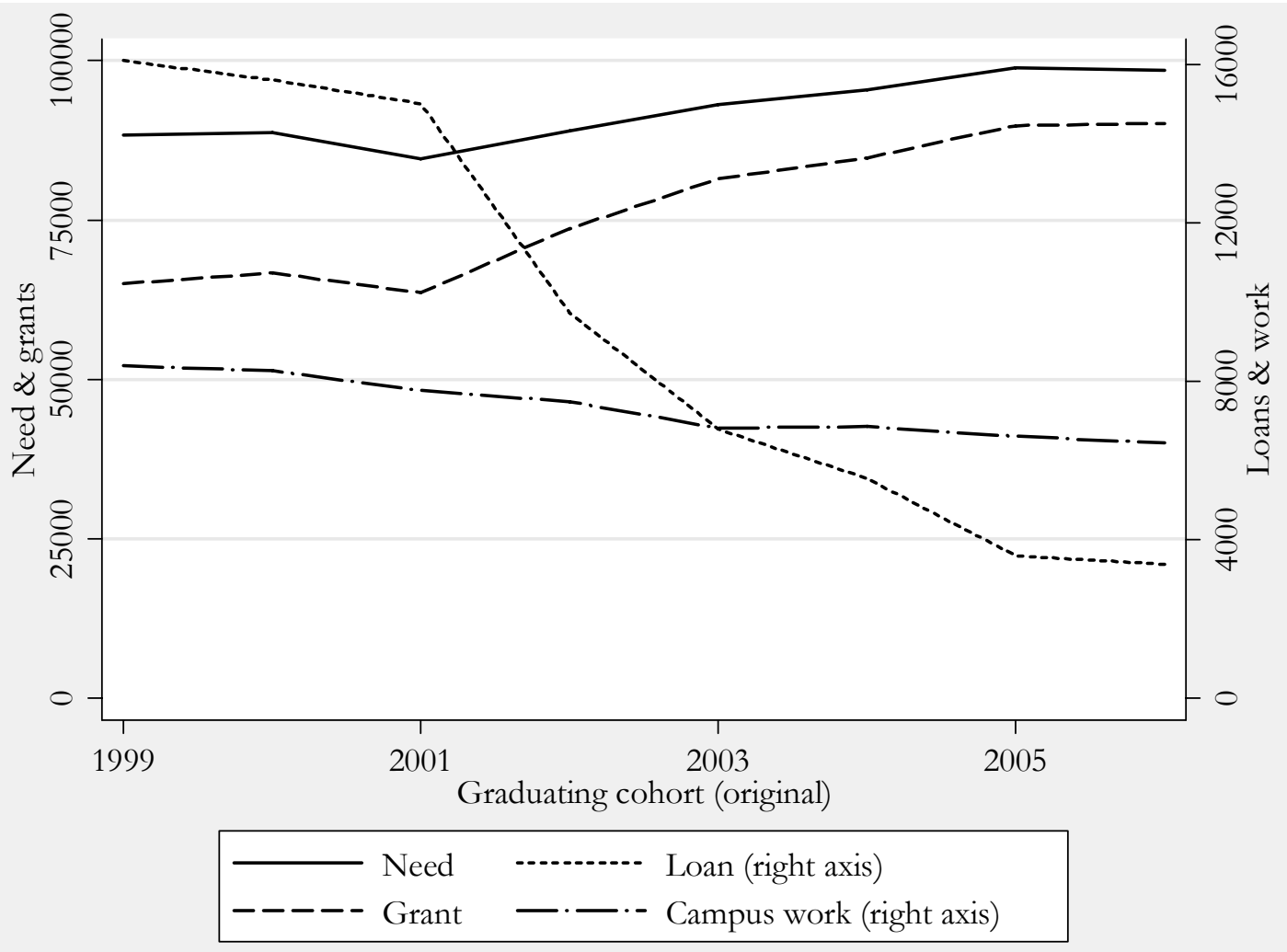


Table 1: Simulated loan and the composition of the realized aid package

\begin{tabular}{lcccc}
\hline & Student loan & Grant & Campus work & Total aid \\
\cline { 2 - 5 } & $\mathbf{( 1 )}$ & $\mathbf{( 2 )}$ & $\mathbf{( 3 )}$ & $\mathbf{( 4 )}$ \\
\hline Simulated loan & 0.77 & -0.90 & 0.08 & -0.06 \\
& $(0.01)$ & $(0.02)$ & $(0.01)$ & $(0.01)$ \\
$\mathrm{R}^{2}$ & 0.65 & 0.98 & 0.68 & 0.99 \\
\hline
\end{tabular}

Notes: $\mathrm{N}=8,893$. Standard errors are in parentheses. Dependent and independent variables are cumulative over four years, and are measured in 2005 dollars. Each specification includes a full set of cohort dummies, a cubic in the cumulative (censored) parental contribution, a set of dummies for the number of years in which the parental contribution was censored, a set of dummies for the number of years that the student applied for aid, and the student's cumulative financial need. 
Table 2. Average characteristics of students, Anon U 1999-2001 and 2005-2006 cohorts

\begin{tabular}{|c|c|c|c|c|c|c|c|}
\hline & \multicolumn{2}{|c|}{ 1999-2001 (pre-reform) } & \multicolumn{2}{|c|}{ 2005-6 (fully treated) } & \multicolumn{2}{|c|}{ Change } & \multirow{2}{*}{$\begin{array}{c}\begin{array}{c}\text { Difference } \\
\text { in } \\
\text { differences }\end{array} \\
(7)\end{array}$} \\
\hline & $\begin{array}{c}\begin{array}{c}\text { Without } \\
\text { need }\end{array} \\
\text { (1) }\end{array}$ & $\begin{array}{c}\begin{array}{c}\text { With } \\
\text { need }\end{array} \\
(2)\end{array}$ & $\begin{array}{c}\begin{array}{c}\text { Without } \\
\text { need }\end{array} \\
(3)\end{array}$ & $\begin{array}{c}\begin{array}{c}\text { With } \\
\text { need }\end{array} \\
(4)\end{array}$ & $\begin{array}{c}\begin{array}{c}\text { Without } \\
\text { need }\end{array} \\
\text { (5) }\end{array}$ & $\begin{array}{c}\begin{array}{c}\text { With } \\
\text { need }\end{array} \\
(6)\end{array}$ & \\
\hline $\mathrm{N}$ & 1,829 & 1,634 & 1,085 & 1,265 & & & \\
\hline SAT & $\begin{array}{c}1,441 \\
{[98]}\end{array}$ & $\begin{array}{l}1,407 \\
{[117]}\end{array}$ & $\begin{array}{c}1,468 \\
{[90]}\end{array}$ & $\begin{array}{l}1,425 \\
{[112]}\end{array}$ & $\begin{array}{l}27 \\
(4)\end{array}$ & $\begin{array}{l}18 \\
(4)\end{array}$ & $\begin{array}{l}-9 \\
(6)\end{array}$ \\
\hline \multicolumn{8}{|l|}{ Race } \\
\hline Black & 0.02 & 0.13 & 0.02 & 0.15 & $\begin{array}{l}-0.003 \\
(0.005)\end{array}$ & $\begin{array}{l}0.017 \\
(0.013)\end{array}$ & $\begin{array}{c}0.020 \\
(0.014)\end{array}$ \\
\hline Hispanic & 0.03 & 0.09 & 0.03 & 0.09 & $\begin{array}{l}-0.001 \\
(0.007)\end{array}$ & $\begin{array}{l}0.005 \\
(0.011)\end{array}$ & $\begin{array}{l}0.006 \\
(0.013)\end{array}$ \\
\hline Asian & 0.13 & 0.15 & 0.14 & 0.15 & $\begin{array}{l}0.006 \\
(0.013)\end{array}$ & $\begin{array}{c}0.001 \\
(0.014)\end{array}$ & $\begin{array}{l}-0.005 \\
(0.019)\end{array}$ \\
\hline Private HS & 0.52 & 0.34 & 0.55 & 0.34 & $\begin{array}{c}0.031 \\
(0.019)\end{array}$ & $\begin{array}{l}0.008 \\
(0.018)\end{array}$ & $\begin{array}{l}-0.023 \\
(0.027)\end{array}$ \\
\hline \multicolumn{8}{|l|}{ Financial need } \\
\hline log(family income) & & $\begin{array}{l}11.19 \\
{[0.68]}\end{array}$ & & $\begin{array}{l}11.27 \\
{[0.83]}\end{array}$ & & $\begin{array}{c}\mathbf{0 . 0 8} \\
(0.03)\end{array}$ & \\
\hline $\begin{array}{l}\text { Family contribution } \\
\text { (per year) }\end{array}$ & & $\begin{array}{c}15,333 \\
{[10,652]}\end{array}$ & & $\begin{array}{c}16,201 \\
{[12,023]}\end{array}$ & & $\begin{array}{c}868 \\
(429)\end{array}$ & \\
\hline Total need & & $\begin{array}{c}86,642 \\
{[45,640]}\end{array}$ & & $\begin{array}{c}99,015 \\
{[51,243]}\end{array}$ & & $\begin{array}{l}12,373 \\
(1,830)\end{array}$ & \\
\hline Total loans & $\begin{array}{c}1,145 \\
{[4,180]}\end{array}$ & $\begin{array}{l}15,485 \\
{[8,311]}\end{array}$ & $\begin{array}{c}496 \\
{[2,785]}\end{array}$ & $\begin{array}{c}3,448 \\
{[6,169]}\end{array}$ & $\begin{array}{l}-649 \\
(129)\end{array}$ & $\begin{array}{c}-12,038 \\
(269)\end{array}$ & $\begin{array}{c}-11,389 \\
(298)\end{array}$ \\
\hline
\end{tabular}

Notes: Need/no need categorization is based whether the student ever had positive need during her time at Anon U. Family income is measured in the freshman year, only for students who had positive need in that year. Family contribution is averaged over a student's time at Anon $U$, censored in each year at the typical cost of attendance in that year and imputed at the censoring point in years that the student did not apply for aid. Standard deviations (for non-binary variables) are shown in square brackets; standard errors are in parentheses. Changes and differences-in-differences in bold are significant at the $10 \%$ level. 
Table 3. Anon U academic and employment outcomes, by cohort and financial need

\begin{tabular}{|c|c|c|c|c|c|c|c|c|}
\hline & \multicolumn{2}{|c|}{ 1999-2001 } & \multicolumn{2}{|c|}{$2005-6$} & \multicolumn{2}{|c|}{ Change } & \multirow{2}{*}{$\begin{array}{l}\text { Diff. } \\
\text { in diffs }\end{array}$} & \multirow{2}{*}{$\begin{array}{c}\text { Wald: } \\
\text { Effect of } \\
\text { \$10K loans }\end{array}$} \\
\hline & $\begin{array}{c}\text { Without } \\
\text { need }\end{array}$ & $\begin{array}{l}\text { With } \\
\text { need }\end{array}$ & $\begin{array}{c}\text { Without } \\
\text { need }\end{array}$ & $\begin{array}{l}\text { With } \\
\text { need }\end{array}$ & $\begin{array}{c}\text { Without } \\
\text { need }\end{array}$ & $\begin{array}{l}\text { With } \\
\text { need }\end{array}$ & & \\
\hline & $(1)$ & $(2)$ & (3) & (4) & (5) & (6) & (7) & (8) \\
\hline \multicolumn{9}{|l|}{ Academic } \\
\hline GPA $(N=4,419)$ & $\begin{array}{c}3.43 \\
{[0.34]}\end{array}$ & $\begin{array}{c}3.30 \\
{[0.41]}\end{array}$ & $\begin{array}{c}3.48 \\
{[0.31]}\end{array}$ & $\begin{array}{c}3.37 \\
{[0.36]}\end{array}$ & $\begin{array}{c}\mathbf{0 . 0 5 0} \\
(0.016)\end{array}$ & $\begin{array}{c}\mathbf{0 . 0 6 4} \\
(0.018)\end{array}$ & $\begin{array}{c}0.015 \\
(0.024)\end{array}$ & $\begin{array}{l}-0.013 \\
(0.021)\end{array}$ \\
\hline Honors $(\mathrm{N}=5,528)$ & 0.49 & 0.40 & 0.49 & 0.40 & $\begin{array}{c}0.000 \\
(0.020)\end{array}$ & $\begin{array}{c}0.002 \\
(0.019)\end{array}$ & $\begin{array}{c}0.002 \\
(0.027)\end{array}$ & $\begin{array}{l}-0.002 \\
(0.024)\end{array}$ \\
\hline \multicolumn{9}{|l|}{ Career } \\
\hline \multicolumn{9}{|c|}{ Post-graduation plans $(\mathrm{N}=5,421)$} \\
\hline Plans graduate school & 0.19 & 0.21 & 0.19 & 0.20 & $\begin{array}{l}-0.004 \\
(0.016)\end{array}$ & $\begin{array}{l}-0.009 \\
(0.016)\end{array}$ & $\begin{array}{l}-0.005 \\
(0.022)\end{array}$ & $\begin{array}{c}0.005 \\
(0.019)\end{array}$ \\
\hline Plans employment & 0.61 & 0.63 & 0.58 & 0.60 & $\begin{array}{l}-0.035 \\
(0.020)\end{array}$ & $\begin{array}{l}-0.028 \\
(0.019)\end{array}$ & $\begin{array}{c}0.006 \\
(0.027)\end{array}$ & $\begin{array}{l}-0.005 \\
(0.024)\end{array}$ \\
\hline Has a job & 0.41 & 0.39 & 0.40 & 0.38 & $\begin{array}{l}-0.007 \\
(0.020)\end{array}$ & $\begin{array}{l}-0.010 \\
(0.019)\end{array}$ & $\begin{array}{l}-0.003 \\
(0.027)\end{array}$ & $\begin{array}{c}0.003 \\
(0.024)\end{array}$ \\
\hline \multicolumn{9}{|c|}{ Industry / occupation (if has a job; $N=2,048$ ) } \\
\hline $\begin{array}{l}\text { Consulting / I-banking / } \\
\text { finance }\end{array}$ & 0.58 & 0.51 & 0.61 & 0.53 & $\begin{array}{c}0.034 \\
(0.031)\end{array}$ & $\begin{array}{c}0.016 \\
(0.032)\end{array}$ & $\begin{array}{l}-0.018 \\
(0.045)\end{array}$ & $\begin{array}{c}0.018 \\
(0.044)\end{array}$ \\
\hline $\begin{array}{l}\text { Any high-salary } \\
\text { industry }\end{array}$ & 0.70 & 0.67 & 0.66 & 0.60 & $\begin{array}{l}-0.039 \\
(0.030)\end{array}$ & $\begin{array}{l}-0.071 \\
(0.031)\end{array}$ & $\begin{array}{l}-0.032 \\
(0.043)\end{array}$ & $\begin{array}{c}0.031 \\
(0.042)\end{array}$ \\
\hline $\begin{array}{l}\text { Nonprofit / govt. / } \\
\text { education }\end{array}$ & 0.18 & 0.17 & 0.15 & 0.22 & $\begin{array}{l}-0.029 \\
(0.023)\end{array}$ & $\begin{array}{c}\mathbf{0 . 0 4 8} \\
(0.026)\end{array}$ & $\begin{array}{c}\mathbf{0 . 0 7 8} \\
(0.035)\end{array}$ & $\begin{array}{l}-0.075 \\
(0.034)\end{array}$ \\
\hline $\begin{array}{l}\text { Any low-salary } \\
\text { industry }\end{array}$ & 0.25 & 0.23 & 0.24 & 0.32 & $\begin{array}{l}-0.006 \\
(0.028)\end{array}$ & $\begin{array}{c}\mathbf{0 . 0 8 5} \\
(0.029)\end{array}$ & $\begin{array}{c}\mathbf{0 . 0 9 1} \\
(0.040)\end{array}$ & $\begin{array}{l}-0.088 \\
(0.039)\end{array}$ \\
\hline \multicolumn{9}{|c|}{ Salary (if has a job; $N=1,689$ ) } \\
\hline Observed & $\begin{array}{c}50,086 \\
{[15,111]}\end{array}$ & $\begin{array}{c}51,025 \\
{[16,243]}\end{array}$ & $\begin{array}{c}52,568 \\
{[17,014]}\end{array}$ & $\begin{array}{c}50,849 \\
{[13,242]}\end{array}$ & $\begin{array}{c}\mathbf{2 , 4 8 2} \\
(1,169)\end{array}$ & $\begin{array}{c}-175 \\
(1,036)\end{array}$ & $\begin{array}{l}-2,657 \\
(1,562)\end{array}$ & $\begin{array}{c}2,585 \\
(1,531)\end{array}$ \\
\hline $\begin{array}{l}\text { Salary below } \$ 41,395 \\
(25 \text { th percentile) } \\
\text { Alumni gifts }(\mathrm{N}=4,531)\end{array}$ & 0.26 & 0.24 & 0.20 & 0.23 & $\begin{array}{l}-0.057 \\
(0.030)\end{array}$ & $\begin{array}{l}-0.004 \\
(0.030)\end{array}$ & $\begin{array}{c}0.052 \\
(0.042)\end{array}$ & $\begin{array}{l}-0.051 \\
(0.041)\end{array}$ \\
\hline $\begin{array}{l}\text { Pledge for 1st year } \\
\text { after graduation }\end{array}$ & $\begin{array}{c}15.2 \\
{[31.0]}\end{array}$ & $\begin{array}{c}11.4 \\
{[12.6]}\end{array}$ & $\begin{array}{c}16.3 \\
{[46.2]}\end{array}$ & $\begin{array}{c}12.9 \\
{[18.4]}\end{array}$ & $\begin{array}{c}1.1 \\
(2.2)\end{array}$ & $\begin{array}{c}1.6 \\
(0.8)\end{array}$ & $\begin{array}{c}0.5 \\
(2.3)\end{array}$ & $\begin{array}{l}-0.4 \\
(2.0)\end{array}$ \\
\hline $\begin{array}{l}\text { Gift in 1st year } \\
\text { after graduation }\end{array}$ & $\begin{array}{c}25.1 \\
{[58.3]}\end{array}$ & $\begin{array}{l}14.6 \\
{[26.8]}\end{array}$ & $\begin{array}{l}25.3 \\
{[55.8]}\end{array}$ & $\begin{array}{c}19.0 \\
{[36.9]}\end{array}$ & $\begin{array}{c}0.2 \\
(2.8)\end{array}$ & $\begin{array}{c}4.4 \\
(1.7)\end{array}$ & $\begin{array}{c}4.3 \\
(3.3)\end{array}$ & $\begin{array}{l}-3.6 \\
(2.8)\end{array}$ \\
\hline
\end{tabular}

Notes: Standard deviations (for non-binary variables) are shown in square brackets; standard errors are in parentheses. Changes and differences-in-differences in bold are significant at the $10 \%$ level. GPAs and alumni gift data are missing for students in the 2006 cohort. Column 8 reports IV estimates of the effect of $\$ 10,000$ in loans, controlling for post-treatment and any need dummies and instrumenting with their interaction. Estimates do not always equal the ratio of the column-7 estimate to 1.1389 (the difference-in-differences estimate for loans, from Table 2) because of missing values in some dependent variables. 
Table 4: Estimates of effects of $\$ 10,000$ in loans on employment outcomes

\begin{tabular}{|c|c|c|c|c|c|c|c|}
\hline & \multirow[b]{2}{*}{$\mathbf{N}$} & \multicolumn{3}{|c|}{ OLS } & \multicolumn{3}{|c|}{ IV } \\
\hline & & $\begin{array}{l}\text { Cohort } \\
\text { dummies }\end{array}$ & $\begin{array}{c}+ \text { controls } \\
\text { for financial } \\
\text { status }\end{array}$ & $\begin{array}{c}+ \\
\text { additional } \\
\text { controls } \\
\end{array}$ & $\begin{array}{l}\text { Cohort } \\
\text { dummies }\end{array}$ & $\begin{array}{c}+ \text { controls } \\
\text { for financial } \\
\text { status } \\
\end{array}$ & $\begin{array}{c}+ \\
\text { additional } \\
\text { controls } \\
\end{array}$ \\
\hline & (1) & (2) & (3) & (4) & (5) & (6) & $(7)$ \\
\hline First stage & 9,287 & & & & $\begin{array}{c}\mathbf{0 . 8 5} \\
(0.01)\end{array}$ & $\begin{array}{c}\mathbf{0 . 7 7} \\
(0.01)\end{array}$ & $\begin{array}{c}\mathbf{0 . 7 7} \\
(0.01)\end{array}$ \\
\hline \multicolumn{8}{|l|}{ Post-graduation plans } \\
\hline Plans graduate school & 8,672 & $\begin{array}{l}-0.002 \\
(0.006)\end{array}$ & $\begin{array}{l}-0.017 \\
(0.008)\end{array}$ & $\begin{array}{l}-0.009 \\
(0.008)\end{array}$ & $\begin{array}{c}0.009 \\
(0.009)\end{array}$ & $\begin{array}{l}-0.006 \\
(0.015)\end{array}$ & $\begin{array}{l}-0.009 \\
(0.015)\end{array}$ \\
\hline Plans employment & 8,672 & $\begin{array}{c}\mathbf{0 . 0 1 2} \\
(0.007)\end{array}$ & $\begin{array}{c}\mathbf{0 . 0 1 9} \\
(0.010)\end{array}$ & $\begin{array}{c}0.009 \\
(0.010)\end{array}$ & $\begin{array}{c}0.002 \\
(0.010)\end{array}$ & $\begin{array}{c}0.011 \\
(0.018)\end{array}$ & $\begin{array}{c}0.011 \\
(0.019)\end{array}$ \\
\hline Has a job & 8,672 & $\begin{array}{l}-0.025 \\
(0.007)\end{array}$ & $\begin{array}{l}-0.016 \\
(0.009)\end{array}$ & $\begin{array}{l}-0.012 \\
(0.009)\end{array}$ & $\begin{array}{l}-0.025 \\
(0.010)\end{array}$ & $\begin{array}{c}0.006 \\
(0.018)\end{array}$ & $\begin{array}{c}0.011 \\
(0.018)\end{array}$ \\
\hline \multicolumn{8}{|c|}{ Industry / occupation (if has a job) } \\
\hline $\begin{array}{l}\text { Consulting / I-banking / } \\
\text { finance }\end{array}$ & 3,020 & $\begin{array}{l}-0.036 \\
(0.012)\end{array}$ & $\begin{array}{l}-0.003 \\
(0.017)\end{array}$ & $\begin{array}{c}0.008 \\
(0.017)\end{array}$ & $\begin{array}{l}-0.063 \\
(0.018)\end{array}$ & $\begin{array}{c}0.006 \\
(0.036)\end{array}$ & $\begin{array}{c}0.015 \\
(0.036)\end{array}$ \\
\hline $\begin{array}{l}\text { Any high-salary } \\
\text { industry }\end{array}$ & 3,020 & $\begin{array}{l}-0.018 \\
(0.012)\end{array}$ & $\begin{array}{l}-0.010 \\
(0.016)\end{array}$ & $\begin{array}{c}0.008 \\
(0.016)\end{array}$ & $\begin{array}{l}-0.020 \\
(0.018)\end{array}$ & $\begin{array}{c}0.014 \\
(0.034)\end{array}$ & $\begin{array}{c}0.014 \\
(0.034)\end{array}$ \\
\hline $\begin{array}{l}\text { Nonprofit / government / } \\
\text { education }\end{array}$ & 3,020 & $\begin{array}{l}-0.012 \\
(0.010)\end{array}$ & $\begin{array}{l}-0.022 \\
(0.013)\end{array}$ & $\begin{array}{l}-0.030 \\
(0.013)\end{array}$ & $\begin{array}{l}-0.004 \\
(0.015)\end{array}$ & $\begin{array}{l}-0.052 \\
(0.028)\end{array}$ & $\begin{array}{l}-0.058 \\
(0.028)\end{array}$ \\
\hline $\begin{array}{l}\text { Any low-salary } \\
\text { industry }\end{array}$ & 3,020 & $\begin{array}{l}-0.001 \\
(0.011)\end{array}$ & $\begin{array}{l}-0.007 \\
(0.015)\end{array}$ & $\begin{array}{l}-0.020 \\
(0.015)\end{array}$ & $\begin{array}{l}-0.006 \\
(0.017)\end{array}$ & $\begin{array}{l}-0.057 \\
(0.032)\end{array}$ & $\begin{array}{l}-0.058 \\
(0.032)\end{array}$ \\
\hline \multicolumn{8}{|l|}{ Salary (if has a job) } \\
\hline Observed & 2,441 & $\begin{array}{c}-84 \\
(399)\end{array}$ & $\begin{array}{l}-472 \\
(558)\end{array}$ & $\begin{array}{c}30 \\
(563)\end{array}$ & $\begin{array}{c}978 \\
(618)\end{array}$ & $\begin{array}{c}2,263 \\
(1,202)\end{array}$ & $\begin{array}{c}2,011 \\
(1,199)\end{array}$ \\
\hline $\begin{array}{l}\text { Salary below } \$ 41,395 \\
\text { (25th percentile) }\end{array}$ & 2,441 & $\begin{array}{c}-0.006 \\
(0.012)\end{array}$ & $\begin{array}{c}-0.005 \\
(0.016)\end{array}$ & $\begin{array}{l}-0.017 \\
(0.016)\end{array}$ & $\begin{array}{c}-0.018 \\
(0.018)\end{array}$ & $\begin{array}{c}-0.059 \\
(0.035) \\
\end{array}$ & $\begin{array}{c}-0.062 \\
(0.035)\end{array}$ \\
\hline
\end{tabular}

Notes: Columns 2 and 5 include a full set of cohort dummies. Columns 3 and 6 add controls for the student's cumulative total need, a 3rd order polynomial in the avg. parental contribution (censored at the budget that applied to the 1999 cohort), and sets of indicators for the number of years the student applied for aid and the number of years the contribution was censored. Columns 4 and 7 add controls for legacy status, firstgeneration college student, recruited athlete, SAT score, admissions ratings of academic and personal qualifications (as sets of dummy variables), a cubic in family income, and the simulated loan under the rules that applied to the 1999 and 2002 cohorts. In columns 5-7, the instrument is the simulated loan for the actual cohort, assuming that the student enrolled in 4 consecutive years. Standard errors are in parentheses; bold coefficients are significant at the $10 \%$ level. 
Table 5. Alternative specifications

\begin{tabular}{|c|c|c|c|c|c|}
\hline & Base & $\begin{array}{l}\text { Using sum of } \\
\text { student and } \\
\text { parent loans }\end{array}$ & $\begin{array}{l}\text { Simulate loans } \\
\text { using rules for } \\
\text { years actually in } \\
\text { attendance }\end{array}$ & $\begin{array}{l}\text { Exclude } 2005 \& \\
2006 \text { cohorts \& } \\
\text { all low-income } \\
\text { students }\end{array}$ & $\begin{array}{l}\text { Control for } \\
\text { SAT-cohort } \\
\text { dummy } \\
\text { interactions }\end{array}$ \\
\hline & $(1)$ & $(2)$ & (3) & $(4)$ & (5) \\
\hline \multirow[t]{2}{*}{ 1st stage } & 0.77 & 0.83 & 0.77 & 0.80 & 0.76 \\
\hline & $(0.01)$ & $(0.08)$ & $(0.01)$ & $(0.02)$ & $(0.01)$ \\
\hline \multirow[t]{2}{*}{ Plans employment } & 0.011 & 0.008 & 0.011 & 0.014 & 0.018 \\
\hline & (0.018) & (0.019) & (0.018) & $(0.027)$ & (0.019) \\
\hline \multirow[t]{2}{*}{ Has a job } & 0.006 & 0.005 & 0.006 & 0.006 & 0.012 \\
\hline & (0.018) & (0.018) & (0.018) & $(0.027)$ & $(0.018)$ \\
\hline \multirow{2}{*}{$\begin{array}{l}\text { Industry: Nonprofit / } \\
\text { government / education }\end{array}$} & -0.052 & -0.043 & -0.056 & -0.028 & -0.060 \\
\hline & $(0.028)$ & $(0.026)$ & $(0.028)$ & $(0.043)$ & $(0.028)$ \\
\hline \multirow[t]{2}{*}{ Salary } & 2,263 & 2,099 & 2,412 & 3,364 & 2,580 \\
\hline & $(1,202)$ & $(1,327)$ & $(1,207)$ & $(1,812)$ & $(1,205)$ \\
\hline
\end{tabular}

Notes: Base specification in column 1 is from column 5 of Table 4 . Other specifications change the endogenous variable (column 2), the instrument (column 3), or the sample (column 4), or add additional control variables (column 5). Standard errors are in parentheses; bold coefficients are significant at the $10 \%$ level. 
Table 6: Estimates of effects of $\$ 10,000$ in loans on major and academic performance at Anon $U$

\begin{tabular}{|c|c|c|c|c|c|c|c|}
\hline & \multirow[b]{2}{*}{$\mathbf{N}$} & \multicolumn{3}{|c|}{ OLS } & \multicolumn{3}{|c|}{ IV } \\
\hline & & $\begin{array}{l}\text { Cohort } \\
\text { dummies }\end{array}$ & $\begin{array}{c}\text { controls } \\
\text { for financial } \\
\text { status }\end{array}$ & $\begin{array}{c}+ \\
\text { additional } \\
\text { controls } \\
\end{array}$ & $\begin{array}{c}\text { Cohort } \\
\text { dummies }\end{array}$ & $\begin{array}{c}+ \text { controls } \\
\text { for financial } \\
\text { status }\end{array}$ & $\begin{array}{c}+ \\
\text { additional } \\
\text { controls } \\
\end{array}$ \\
\hline & (1) & (2) & (3) & (4) & (5) & $(6)$ & $(7)$ \\
\hline \multicolumn{8}{|l|}{ Division } \\
\hline Social sciences & 9,166 & $\begin{array}{c}0.000 \\
(0.007)\end{array}$ & $\begin{array}{c}\mathbf{0 . 0 2 6} \\
(0.009)\end{array}$ & $\begin{array}{c}0.011 \\
(0.009)\end{array}$ & $\begin{array}{l}-0.034 \\
(0.010)\end{array}$ & $\begin{array}{l}-0.003 \\
(0.018)\end{array}$ & $\begin{array}{l}-0.012 \\
(0.018)\end{array}$ \\
\hline Humanities & 9,166 & $\begin{array}{l}-0.009 \\
(0.006)\end{array}$ & $\begin{array}{c}\mathbf{0 . 0 1 6} \\
(0.008)\end{array}$ & $\begin{array}{c}\mathbf{0 . 0 1 8} \\
(0.008)\end{array}$ & $\begin{array}{l}-0.017 \\
(0.009)\end{array}$ & $\begin{array}{l}-0.008 \\
(0.015)\end{array}$ & $\begin{array}{l}0.000 \\
(0.015)\end{array}$ \\
\hline Physical sciences & 9,166 & $\begin{array}{c}0.005 \\
(0.005)\end{array}$ & $\begin{array}{l}-0.012 \\
(0.007)\end{array}$ & $\begin{array}{l}-0.010 \\
(0.008)\end{array}$ & $\begin{array}{c}0.012 \\
(0.008)\end{array}$ & $\begin{array}{l}-0.005 \\
(0.014)\end{array}$ & $\begin{array}{l}-0.010 \\
(0.015)\end{array}$ \\
\hline Engineering & 9,166 & $\begin{array}{c}0.004 \\
(0.005)\end{array}$ & $\begin{array}{l}-0.029 \\
(0.007)\end{array}$ & $\begin{array}{l}-0.018 \\
(0.007)\end{array}$ & $\begin{array}{c}0.039 \\
(0.008)\end{array}$ & $\begin{array}{c}0.016 \\
(0.013)\end{array}$ & $\begin{array}{c}0.022 \\
(0.013)\end{array}$ \\
\hline \multicolumn{8}{|l|}{ Specific majors/certificates } \\
\hline $\begin{array}{l}\text { Econ. or engineering } \\
\text { major or finance certif. }\end{array}$ & 8,792 & $\begin{array}{c}0.001 \\
(0.006)\end{array}$ & $\begin{array}{l}-0.033 \\
(0.009)\end{array}$ & $\begin{array}{l}-0.020 \\
(0.009)\end{array}$ & $\begin{array}{c}\mathbf{0 . 0 3 9} \\
(0.010)\end{array}$ & $\begin{array}{c}0.020 \\
(0.017)\end{array}$ & $\begin{array}{c}0.025 \\
(0.017)\end{array}$ \\
\hline Non-renumerative major & 8,792 & $\begin{array}{l}-0.001 \\
(0.007)\end{array}$ & $\begin{array}{c}\mathbf{0 . 0 4 7} \\
(0.010)\end{array}$ & $\begin{array}{c}\mathbf{0 . 0 2 9} \\
(0.010)\end{array}$ & $\begin{array}{l}-0.042 \\
(0.011)\end{array}$ & $\begin{array}{l}-0.019 \\
(0.018)\end{array}$ & $\begin{array}{l}-0.023 \\
(0.018)\end{array}$ \\
\hline $\begin{array}{l}\text { Public affairs or } \\
\text { teaching certificate }\end{array}$ & 8,792 & $\begin{array}{l}-0.005 \\
(0.004)\end{array}$ & $\begin{array}{l}-0.005 \\
(0.005)\end{array}$ & $\begin{array}{c}0.000 \\
(0.005)\end{array}$ & $\begin{array}{l}-0.006 \\
(0.006)\end{array}$ & $\begin{array}{l}0.004 \\
(0.010)\end{array}$ & $\begin{array}{c}0.009 \\
(0.010)\end{array}$ \\
\hline $\begin{array}{l}\text { Non-renumerative } \\
\text { certificate }\end{array}$ & 8,792 & $\begin{array}{c}0.001 \\
(0.004)\end{array}$ & $\begin{array}{c}0.005 \\
(0.005)\end{array}$ & $\begin{array}{c}0.006 \\
(0.005)\end{array}$ & $\begin{array}{l}-0.002 \\
(0.005)\end{array}$ & $\begin{array}{c}0.002 \\
(0.010)\end{array}$ & $\begin{array}{c}0.006 \\
(0.010)\end{array}$ \\
\hline GPA & 7,773 & $\begin{array}{c}-0.098 \\
(0.005)\end{array}$ & $\begin{array}{l}-0.088 \\
(0.007)\end{array}$ & $\begin{array}{l}-0.048 \\
(0.006)\end{array}$ & $\begin{array}{l}-0.091 \\
(0.008)\end{array}$ & $\begin{array}{l}-0.036 \\
(0.014)\end{array}$ & $\begin{array}{l}-0.015 \\
(0.012)\end{array}$ \\
\hline Honors & 8,893 & $\begin{array}{l}-\mathbf{- 0 . 0 8 2} \\
(0.007)\end{array}$ & $\begin{array}{l}-0.075 \\
(0.009)\end{array}$ & $\begin{array}{c}-0.040 \\
(0.009)\end{array}$ & $\begin{array}{c}-0.071 \\
(0.010)\end{array}$ & $\begin{array}{l}-0.028 \\
(0.018)\end{array}$ & $\begin{array}{l}-0.013 \\
(0.017)\end{array}$ \\
\hline
\end{tabular}

Notes: See notes to table 4. 
Table 7: IV-Control function estimates of effects of $\$ 10,000$ in loans on alumni giving

\begin{tabular}{|c|c|c|c|c|c|c|}
\hline & \multirow[b]{3}{*}{ (1) } & \multicolumn{2}{|c|}{ Participation (0/1) } & \multicolumn{2}{|c|}{ Amount } & \multirow{3}{*}{$\begin{array}{c}\begin{array}{c}\text { Fall short of } \\
\text { pledge }\end{array} \\
\end{array}$} \\
\hline & & Pledge & Gift & Pledge & Gift & \\
\hline & & (2) & (3) & (4) & (5) & \\
\hline \multirow[t]{2}{*}{ Year 1} & 7,768 & -0.001 & -0.035 & -0.5 & -3.4 & 0.047 \\
\hline & & (0.017) & (0.019) & (0.9) & (1.9) & $(0.017)$ \\
\hline \multirow[t]{2}{*}{ Year 2} & 6,629 & 0.000 & -0.034 & -1.1 & -1.6 & 0.029 \\
\hline & & (0.020) & (0.023) & (1.3) & (2.5) & $(0.023)$ \\
\hline \multirow[t]{2}{*}{ Year 3} & 5,516 & 0.009 & -0.028 & -1.3 & -7.9 & 0.031 \\
\hline & & $(0.026)$ & (0.028) & (2.0) & (3.6) & $(0.029)$ \\
\hline \multirow[t]{2}{*}{ Year 4} & 4,402 & -0.036 & 0.027 & -8.1 & -0.6 & -0.023 \\
\hline & & $(0.037)$ & $(0.041)$ & $(4.8)$ & $(6.0)$ & $(0.044)$ \\
\hline
\end{tabular}

Notes: Samples exclude cohorts for which gift data are not yet available (class of 2006 in row 1, 2005-6 in row 2, 2004-6 in row 3, and 2003-6 in row 4). Bold coefficients are significant at the 10\% level. 
Table 8. Comparison of Anon $U$ and Nationally Representative Aid Recipients

\begin{tabular}{lcccc}
\hline & $\begin{array}{c}\text { Anon U: Aid } \\
\text { recipients from } \\
\text { the classes of } \\
\text { 1999-2001 }\end{array}$ & \multicolumn{2}{c}{$\begin{array}{c}\mathbf{1 9 9 9 - 2 0 0 0 ~ N P S A S : ~ F u l l - t i m e , ~ 1 8 - 2 4 ~ y e a r ~ o l d ~} \\
\text { dependent seniors with positive aid }\end{array}$} \\
\cline { 2 - 5 } & $\mathbf{( 1 )}$ & $\begin{array}{c}\text { Comparable } \\
\text { private }\end{array}$ & $\begin{array}{c}\text { Comparable public } \\
\text { \& private }\end{array}$ & $\begin{array}{c}\text { All four-year } \\
\text { institutions }\end{array}$ \\
\hline SAT & 1,407 & $\mathbf{( 2 )}$ & $\mathbf{( 3 )}$ & $\mathbf{( 4 )}$ \\
Race & {$[116]$} & 1,102 & 1,089 & 1,087 \\
White & & {$[177]$} & {$[174]$} & {$[173]$} \\
Asian & $60 \%$ & & & \\
Black/Hispanic & $16 \%$ & $80 \%$ & $75 \%$ & $74 \%$ \\
Private HS & $24 \%$ & $3 \%$ & $6 \%$ & $6 \%$ \\
Family Income & $33 \%$ & $14 \%$ & $18 \%$ & $18 \%$ \\
& 93,251 & $21 \%$ & $15 \%$ & $15 \%$ \\
Family income $<\$ 60,000$ & {$[52,092]$} & 83,859 & 74,427 & 74,278 \\
Cumulative federal student & $30 \%$ & {$[49,149]$} & {$[46,337]$} & {$[46,264]$} \\
loans & 16,597 & $36 \%$ & $43 \%$ & $43 \%$ \\
$\mathrm{~N}$ & {$[7,877]$} & 30,479 & 26,985 & 27,039 \\
\hline
\end{tabular}

Notes: Means; standard deviations in brackets. "Comparable" schools include public and private not-for-profit colleges and universities in the Carnegie categories Research I and II, PhD Granting I and II, Comprehensive I and II, and Liberal Arts I and II. NPSAS sample is restricted to full-time dependent seniors aged 18-24 with positive need-based aid in their senior years, and is weighted by the study weight. Anon $U$ sample is similarly restricted to students with positive need in the senior year. All dollar figures are in 2005 dollars. 